\title{
TanP: A Multifunctional Anionic Peptide From Tityus stigmurus Scorpion Venom
}

Menilla Maria Alves de Melo ${ }^{1}$, Verônica da Silva Oliveira ${ }^{2}$, Moacir Fernandes de Queiroz Neto ${ }^{3}$, Weslley de Souza Paiva ${ }^{3}$, Manoela Torres-Rêgo ${ }^{1,4}$, Sérgio Ruschi Bergamachi Silva ${ }^{5}$, Daniel de Lima Pontes ${ }^{2}$, Hugo Alexandre Oliveira Rocha ${ }^{3}$, Miguel Ângelo Fonseca de Souza ${ }^{6}$, Arnóbio Antônio da Silva-Júnior ${ }^{1}$ and Matheus de Freitas Fernandes-Pedrosa ${ }^{1 *}$

\section{OPEN ACCESS}

Edited by:

Maria Elena De Lima, Grupo Santa Casa BH, Brazil

Reviewed by: Juliana Carvalho Tavares, Federal University of Minas Gerais,

Brazil

Thiago Verano-Braga, Federal University of Minas Gerais,

Brazil

Rodrigo Moreira Verly, Universidade Federal dos Vales do Jequitinhonha e Mucuri (UFVJM),

Brazil

*Correspondence: Matheus de Freitas Fernandes-

Pedrosa

mffpedrosa@gmail.com

Specialty section:

This article was submitted to Cellular Biochemistry,

a section of the journal

Frontiers in Molecular Biosciences

Received: 29 September 2021

Accepted: 13 December 2021

Published: 17 January 2022

Citation:

Melo MMAd, Oliveira VdS,

Queiroz Neto MFd, Paiva WdS,

Torres-Rêgo M, Silva SRB,

Pontes DdL, Rocha HAO,

Souza MÂFd, Silva-Júnior AAd and Fernandes-Pedrosa MdF (2022) TanP: A Multifunctional Anionic Peptide From

Tityus stigmurus Scorpion Venom.

Front. Mol. Biosci. 8:785316.

doi: 10.3389/fmolb.2021.785316
${ }^{1}$ Laboratory of Pharmaceutical Technology and Biotechnology, Department of Pharmacy, Federal University of Rio Grande do Norte, Natal, Brazil, ${ }^{2}$ Laboratory of Coordination Chemistry and Polymers, Institute of Chemistry, Federal University of Rio Grande do Norte, Natal, Brazil, ${ }^{3}$ Laboratory of Natural Polymer Biotechnology, Department of Biochemistry, Federal University of Rio Grande do Norte, Natal, Brazil, ${ }^{4}$ Laboratory of Synthesis and Isolation of Organic Compounds, Chemistry Institute, Federal University of Rio Grande do Norte, Natal, Brazil, ${ }^{5}$ Institute of Brain, Federal University of Rio Grande do Norte, Natal, Brazil, ${ }^{6}$ Laboratory of Computational Chemistry, Institute of Chemistry, Federal University of Rio Grande do Norte, Natal, Brazil

Anionic peptides of scorpions are molecules rich in aspartic and/or glutamic acid residues and correspond to a class of peptides without disulfide bonds that are still little explored. TanP is a linear anionic peptide (50 amino acid residues and net charge -20) present in the venom gland of the scorpion, Tityus stigmurus, with chelating properties for $\mathrm{Cu}^{2+}$ ion and immunomodulatory properties. The therapeutic application of chelating molecules is related to cases of acute or chronic intoxication by metals, neurodegenerative diseases, hematological diseases, healing of skin wounds, cardiovascular diseases, and cancer. In this approach, the chelating activity of $\mathrm{TanP}$ was evaluated in relation to new metal ions $\left(\mathrm{Fe}^{2+}\right.$ and $\left.\mathrm{Zn}^{2+}\right)$ of biological importance, as well as its antioxidant, hemostatic, immunomodulatory, and healing potential, aiming to expand the biological and biotechnological potential of this peptide. TanP $(25 \mu \mathrm{M})$ was able to form stable complexes with $\mathrm{Fe}^{2+}$ in a ratio of 1:5 (TanP: $\left.\mathrm{Fe}^{2+}\right)$. Theoretical results suggest that TanP can work as a sensor to identify and quantify $\mathrm{Fe}^{2+}$ ions. The fluorescence intensity of $\mathrm{TanP}$ $(1.12 \mu \mathrm{M})$ decreased significantly after the addition of $\mathrm{Fe}^{2+}$, obtaining the highest ratio 1: 7.4 ( $\left(\mathrm{TanP}: \mathrm{Fe}^{2+}\right.$ ) that led to the lowest fluorescence intensity. For $\mathrm{Zn}^{2+}$, no relevant spectral change was noted. TanP $(50 \mu \mathrm{M})$ showed a maximum of $3 \%$ of hemolytic activity, demonstrating biocompatibility, as well as exhibiting a 1,1-diphenyl-2-picrylhydrazyl radical-scavenging activity of above $70 \%$ at all the concentrations tested $(1-25 \mu \mathrm{M})$, and $89.7 \%$ iron-chelating activity at $25 \mu \mathrm{M}$ and $96 \%$ hydroxyl radical-scavenging activity at $73.6 \mu \mathrm{M}$. In addition, TanP (12.5 and $25 \mathrm{\mu M}$ ) revealed an anticoagulant effect, prolonging the clotting time in prothrombin time and activated partial thromboplastin time assays, with no fibrinogenolytic activity. TanP (12.5 and $25 \mu \mathrm{M})$ induced the release of TNF- $\alpha$ by murine macrophages, in the absence of lipopolysaccharides, with a concentration-dependent increase and also stimulated the migration of 3 T3 cells in the in vitro healing assay. Thus, TanP revealed a multifunctional potential, being useful as a prototype for the development of new therapeutic and biotechnological agents.

Keywords: anionic peptide, chelating, antioxidant, immunomodulatory, Tityus stigmurus scorpion 


\section{INTRODUCTION}

Anionic, or acidic, peptides are a new class of scorpion venom peptides, which have been rarely identified and poorly characterized so far but are widely present in the venom glands of all detected species of scorpions (Shi et al., 2018). These molecules are peptides without disulfide bonds, rich in aspartic and glutamic acid residues, with an isoelectric point less than 5.0, showing high hydrophilic properties and secondary structures composed by random regions, $\alpha$-helix domains, and spiral structures (Nie et al., 2012; Shi et al., 2018).

Regarding Tityus genus, an abundant presence of anionic peptides has been reported, with the observation that 27.22, $7.75,4.9$, and $3.14 \%$ of the total toxins expressed in the venom of scorpions Tityus stigmurus (Almeida et al., 2012), Tityus serrulatus (Alvarenga et al., 2012), Tityus bahiensis (Oliveira et al., 2015), and Tityus obscurus (de Oliveira et al., 2018), respectively, correspond to anionic peptides. The scorpions Centruroides tecomanus (Valdez-Velázquez et al., 2013), Buthus martensii Karsch (Zeng et al., 2005), Centruroides hirsuti-palpus (Valdez-Velázquez et al., 2020), and Mesobuthus eupeus (Baradaran et al., 2018) also showed an anionic peptide in the venom composition.

In a previous study carried out by our research group, an anionic peptide present in the $T$. stigmurus scorpion venom gland, named TanP (T. stigmurus anionic peptide) was characterized for the first time, with a negative charge of -20 and a theoretical isoelectric point of 2.75. In vitro assays have demonstrated that TanP has the chelating activity of $\mathrm{Cu}^{2+}$ ions and revealed an immunomodulatory potential, since it induced the proliferation of macrophages and reduced the release of nitric oxide by these cells, in the presence of lipopolysaccharides (LPS) (Melo et al., 2017).

Anionic peptides from vertebrate and invertebrate animals have demonstrated antimicrobial, immunomodulatory, and metal-chelating action (Lai et al., 2002; Silva et al., 2009; Segura-Ramírez and Silva Júnior, 2018; Zhang et al., 2021), which are part of the host defense system in scorpions and other phyla (Valdez-Velázquez et al., 2020). The use of metallopharmacology techniques (Flora and Pachauri, 2010) is useful for restoring the normal healthy physiology of the body, with wide therapeutic applications in cases of acute or chronic intoxication by metals (Andersen, 2004; Ward et al., 2012; Smith, 2013), neurodegenerative diseases (Ward et al., 2012; BenShushan and Miller, 2021), hematological diseases (Pretorius et al., 2014; Leitch and Gattermann, 2019), cutaneous wound healing (Wright et al., 2014), cardiovascular diseases (Smith, 2013), and cancer (Yu et al., 2012; Antoniades et al., 2013). The use of small molecules or chelating peptides corresponds to an attractive strategy both to understand the fundamentals of biological regulation of the metal and to develop new therapies (Wang and Franz, 2016; Caetano-Silva et al., 2021; Zeng et al., 2021).

Recently, some researchers have demonstrated the multifunctionality of linear peptides present in scorpions (D'Suze et al., 2010; Gao et al., 2010; Guo et al., 2013; Ortiz et al., 2015; Daniele-Silva et al., 2016, 2021; Guilhelmelli et al.,
2016; Ojeda et al., 2016; Cesa-Luna et al., 2019), and their antibacterial, antifungal, hypotensive, anticancer, and immunomodulatory activities have been identified (Zeng et al., 2012; Almaaytah et al., 2013; Daniele-Silva et al., 2016, 2021; Machado et al., 2016; Torres-Rêgo et al., 2019; Furtado et al., 2020). However, little researches about anionic peptides of these arachnids have been reported. In this approach, the evaluation of the chelating activity of TanP was carried out in relation to new metals of biological importance and expanding the investigation of its biological potential.

\section{MATERIALS AND METHODS}

\section{Tityus stigmurus Anionic Peptide (TanP) Synthesis}

The peptide TanP was deduced from the cDNA clone TSTI0006C obtained from T. stigmurus transcriptome (Almeida et al., 2012). The synthetic mature peptide (YPASFDDDFDALDDLDDLDLD DLLDLEPADLVLLDMWANMMDSQDFEDFE) was obtained from Aminotech (Minas Gerais, Brazil) with purity higher than $90 \%$ and was maintained at $-20^{\circ} \mathrm{C}$ until the time of use. The peptide tests were conducted under authorization from the National System for Management of Genetic Heritage and Associated Traditional Knowledge (SisGen), under the registration number AAF17D9 (April 24th, 2018).

\section{TanP-Bivalent Metal Reactivity Assay}

The reactivity of TanP with bivalent ions $\left(\mathrm{Fe}^{2+}\right.$ and $\left.\mathrm{Zn}^{2+}\right)$ was evaluated by spectroscopy technique, using the methodology described by Melo et al. (2017). In brief, TanP $(25 \mu \mathrm{M})$, in the absence or presence of the ions $\left(\mathrm{Fe}^{2+}\right.$ and $\left.\mathrm{Zn}^{2+}\right)$ at increasing concentrations $(0-175 \mu \mathrm{M})$ was incubated at room temperature $\left(25^{\circ} \mathrm{C}\right)$ for $5 \mathrm{~min}$. Then, the absorbance of the mixture was measured between 190 and $800 \mathrm{~nm}$ in a quartz cuvette $(1 \mathrm{~cm}$ optical path), using the spectrophotometer Agilent 8453 UVvisible Spectroscopy System (Agilent, Santa Clara, California, United States of America) with a DAD detector. Electronic spectra were generated for the evaluation of complexation. The stoichiometric ratio for the complex was obtained from the extrapolation calculation of the lines, equaling the values of the $y$-axis of each of the equations of the lines, thus obtaining the value of $\mathrm{x}$, corresponding to the concentration of the metal in the sample.

\section{Fluorescence Emission Spectrophotometry}

Fluorescence spectra were recorded with a spectrofluorometer (RF-5301PC model Shimadzu, Japan), with $280 \mathrm{~nm}$ excitation wavelength. The emission spectrum was recorded in the range of 300-500 nm. All measurements were performed with wide slits of excitation and emission equal to 1.5 and $15 \mathrm{~nm}$, respectively. The TanP sample $(1.12 \mu \mathrm{M})$ was titrated with the increasing concentrations of $\mathrm{Fe}^{2+}(0-47.7 \mu \mathrm{M})$ or $\mathrm{Zn}^{2+}(0-50 \mu \mathrm{M})$ ions, obtained from $\mathrm{FeSO}_{4} \cdot 7 \mathrm{H}_{2} \mathrm{O}$ or $\mathrm{ZnCl}_{2}$ solutions, respectively. After $5 \mathrm{~min}$ of the addition of the ions, the fluorescence emission spectra were obtained, and the results were expressed as fluorescence intensity vs. wavelength (nm) (Croney, 2001; 

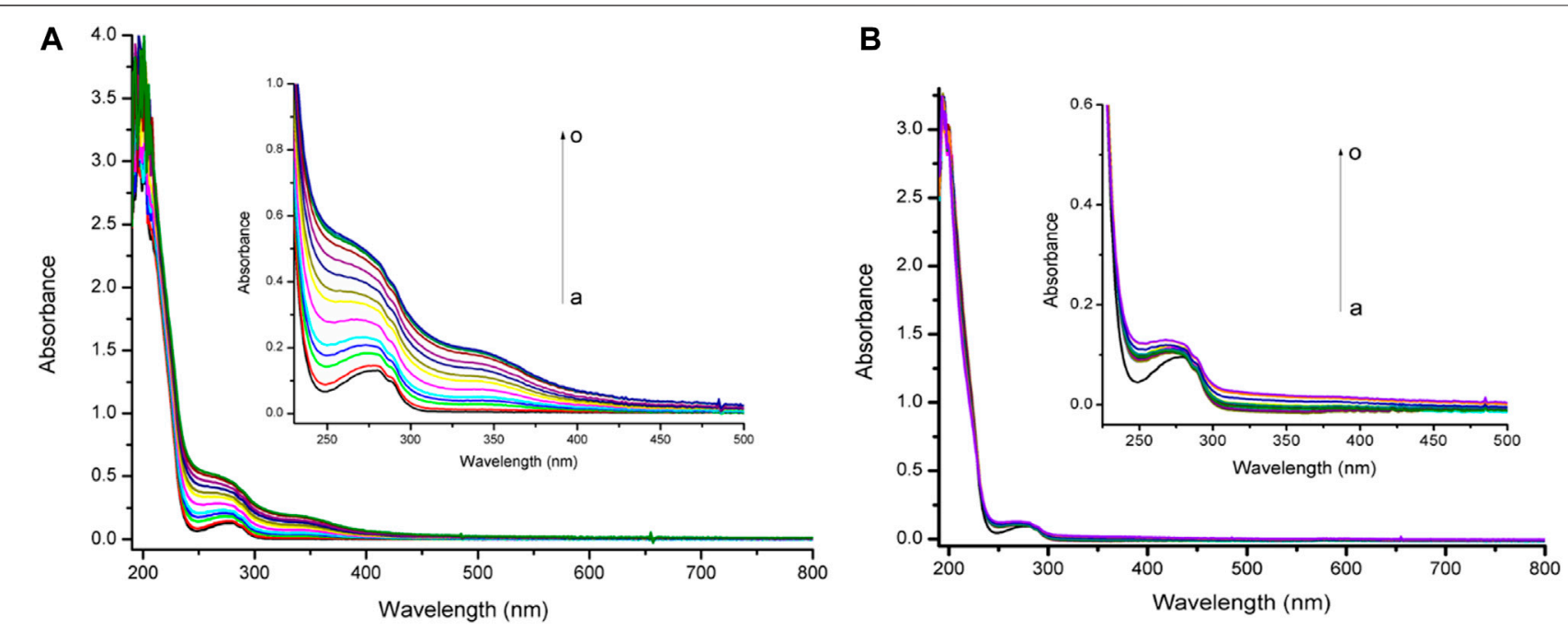

FIGURE 1 | Uv-vis absorption spectra of TanP $(25 \mu \mathrm{M})$ upon the addition of different concentrations of (A) Fe ${ }^{2+}$ and (B) $\mathrm{Zn}^{2+}$, curves a-o (0-175 $\left.\mu \mathrm{M}\right)$.
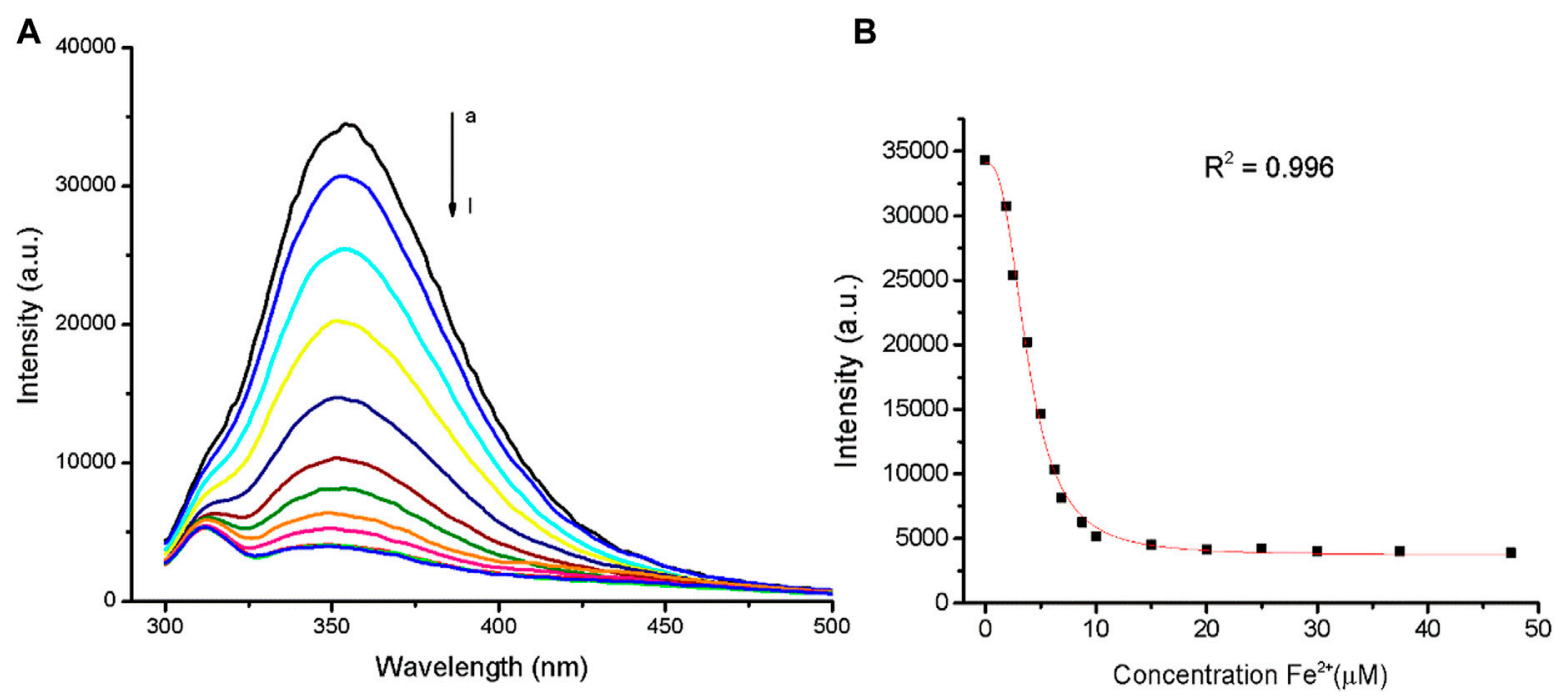

FIGURE 2 | Quenching effects of Fe ${ }^{2+}$ on TanP $(1.12 \mu \mathrm{M})$ fluorescence intensity, with $\lambda_{\mathrm{ex}}=280 \mathrm{~nm}$. (A) Addition of iron ion, curves a-I (0-47.7 $\left.\mu \mathrm{M}\right)$. (B) Fluorescence intensity of TanP at $353 \mathrm{~nm}$ with increased $\mathrm{Fe}^{2+}$.

Caetano-Silva et al., 2017). All samples were measured in a quartz cuvette (path length $1 \mathrm{~cm}$ ). For the titration of the iron and zinc ions, 12 and 14 spectra were obtained, respectively.

\section{Computational Methods}

Theoretical calculations were focused on proposing a probable mechanism of interaction between the metallic center and TanP, particularly through their carboxylate groups belonging to the side chains of the aspartate and glutamate residues. Previous experimental results for $\mathrm{Cu}^{2+}$ ions and TanP indicate that this chelating process takes place via carboxylate pairs located throughout the tertiary structure (Melo et al., 2017). Hence, a complexation model, among an acetate pair, water molecules, and metal ions $\left(\mathrm{Fe}^{2+}\right.$ and $\left.\mathrm{Zn}^{2+}\right)$, was tried to support and understand the chelating effect. The use of acetate to describe the Asp/metals interaction is feasible since the difference in local electron density is minimal and the interaction site remains the same. A conformational search was carried out using the Conformer-Rotamer Ensemble Sampling Tool CREST version 2.10.2 (Pracht et al., 2020) 


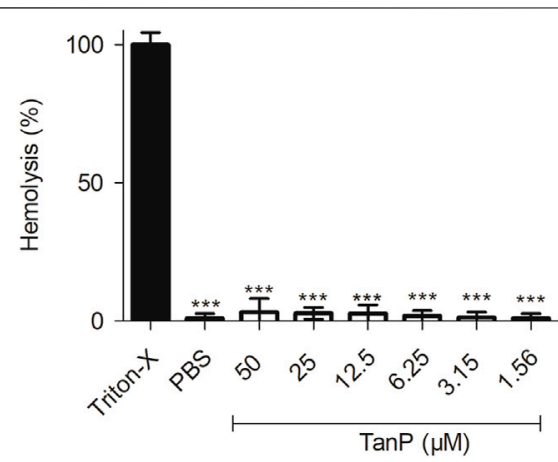

FIGURE 3 | Hemolytic activity of TanP in vitro. TanP was tested $(1.56-50 \mu \mathrm{M})$, the statistical significance was performed using ANOVA followed by Tukey's test and expressed as mean \pm SD $(n=3) .{ }^{* * *} p<0.001$ compared with the positive control group (Triton-X).

with the xtb program package (Bannwarth et al., 2021). The semiempirical tight-binding-based quantum chemistry method GFN2-xTB was used in the framework of meta-dynamics to globally explore the conformers (Grimme, 2019). The best conformer for each metal was subjected to density functional theory (DFT) geometry optimization at the BP86 (Perdew, 1986; Becke, 1988)/def2-TZVP (Perdew, 1986; Becke, 1988; Weigend and Ahlrichs, 2005) level of theory in an implicit solvent (water) using the polarizable continuum model (IEFPCM) (Scalmani and Frisch, 2010). After optimization calculations, the TD-DFT (Pracht et al., 2020) model for predicting vertical transition energies of the first excited state was performed at the CAM-B3LYP (Yanai et al., 2004)/def2TZVP. Furthermore, natural bond orbital (NBO) (Foster and Weinhold, 1980; Reed and Weinhold, 1983) and natural transition orbital (NTO) (Martin, 2003) analyses were also carried out to provide a more intuitive picture of the molecular orbitals. The Gaussian 16 program was used for all DFT calculations (Frisch et al., 2016).

\section{Hemolytic Activity}

The hemolytic effect of TanP was determined previously by de Menezes et al. (2014), with modifications. In brief, the suspension of $1 \%(\mathrm{v} / \mathrm{v})$ healthy human erythrocytes (blood group $\mathrm{O}^{+} \mathrm{Rh}^{+}$) was incubated with TanP $(1.56-50 \mu \mathrm{M})$ for $1 \mathrm{~h}$ at $37^{\circ} \mathrm{C}$. After this period, the samples were centrifuged at $1,500 \mathrm{rpm}$ for $10 \mathrm{~min}$ at $25^{\circ} \mathrm{C}$ (Eppendorf ${ }^{\circledast} 5424 \mathrm{R}$, Germany). Then, $200 \mu \mathrm{l}$ of the supernatant was transferred to a 96 -well microplate, and the absorbance of the hemoglobin was measured at $540 \mathrm{~nm}$ using the microplate reader (EpochBiotek $^{\circledR}$, Vermont, United States of America). Triton X-100 $1 \%(\mathrm{v} / \mathrm{v})$ and phosphate-buffered saline (137 mM NaCl, $3 \mathrm{mM}$ $\mathrm{KCl}, 1.5 \mathrm{mM} \mathrm{KH}_{2} \mathrm{PO}_{4}$, and $\left.10 \mathrm{mM} \mathrm{Na}_{2} \mathrm{HPO}_{4} ; \mathrm{pH}, 7.4\right)$ were used as the positive control $(100 \%$ hemolysis $)$ and the negative control ( $0 \%$ hemolysis), respectively. The results were expressed as the percentage of red cell lysis compared with the positive control (100\% lysis). For the use of blood from a healthy human donor, the project was previously approved by the research ethics committee of the Hospital Universitário Onofre Lopes-Huol/UFRN, under the number 3127063.

\section{In Vitro Antioxidant Activity}

\section{1,1-Diphenyl-2-picrylhydrazyl Scavenging Assay}

The 1,1-diphenyl-2-picrylhydrazyl

(DPPH)

radical-scavenging activity evaluated the ability of TanP to donate hydrogen or scavenge the DPPH radical in an ethanol solution. This method is based on the reduction of the DPPH radical (very unstable nitrogen radical and is purple). When reacting with reducing substances, that is, antioxidants, it is transformed into diphenyl-picryl-hydrazine (DPPH-H) which is yellow. The DPPH radical-scavenging effect was measured using the method described by Melo-Silveira et al. (2014), with modifications. In brief, $100 \mu$ l of TanP $(1-25 \mu \mathrm{M})$ was mixed with $100 \mu \mathrm{l}$ of ethanol solution of DPPH $(150 \mu \mathrm{M})$ and incubated for $30 \mathrm{~min}$, protected from light, at room temperature $\left(25^{\circ} \mathrm{C}\right)$. After incubation, the absorbance was measured at $517 \mathrm{~nm}$. The DPPH freeradical-scavenging activity (DPPH-FSA) was determined using the following equation, where the blank sample is ethanol solution and the blank control is DPPH solution:

DPPH - FSA $(\%)=\left[1-\frac{(\text { absorbance of sample }- \text { absorbance of blank sample })}{(\text { absorbance of control }- \text { absorbance of blank control })}\right] \times 100$

\section{Hydroxyl Radical-Scavenging Assay}

The hydroxyl radical-scavenging effect of TanP was investigated using Fenton's reaction $\left(\mathrm{Fe}^{2+}+\mathrm{H}_{2} \mathrm{O}_{2} \rightarrow \mathrm{Fe}^{3+}+\mathrm{OH}^{-}+\mathrm{OH} \bullet\right)$ as previously described in the literature, with few modifications (Melo-Silveira et al., 2014). In 96-well microplates, TanP $(1-73.6 \mu \mathrm{M})$ was incubated with the reagent solution $[10 \mathrm{mM}$ ferrous sulfate, $10 \mathrm{mM}$ ethylenediaminetetraacetic acid (EDTA), $2 \mathrm{mM}$ sodium salicylate, and $30 \%$ hydrogen peroxide in $150 \mathrm{mM}$

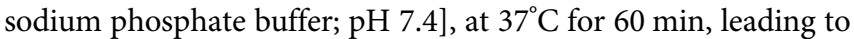
the formation of the hydroxyl radical. Then, the absorbance of hydroxyl radicals was measured at $510 \mathrm{~nm}$. Tubes in the absence of hydrogen peroxide were used as blank tubes. The results were expressed as percentage of scavenging compared to the standard gallic acid $(0.25-2 \mathrm{mg} / \mathrm{ml})$.

\section{Superoxide Radical-Scavenging Assay}

The superoxide radical-scavenging activity was determined as described by Melo-Silveira et al. (2014). The reaction mixture containing TanP at different concentrations (1-25 $\mu \mathrm{M}), 50 \mathrm{mM}$ sodium phosphate buffer ( $\mathrm{pH} 7.4$ ), $65 \mathrm{mM}$ methionine, $0.5 \mathrm{mM}$ EDTA, 0.375 nitrotetrazolium blue chloride, and $0.5 \mathrm{mM}$ riboflavin were exposed to 15-min illumination with a fluorescent lamp. The change in color was measured $(560 \mathrm{~nm})$ with a spectrophotometer. The control and blank mixtures were prepared. The blank was protected from light. The results were expressed as the percentage of hydroxyl radical-scavenging activity, as shown in the previous equation. 

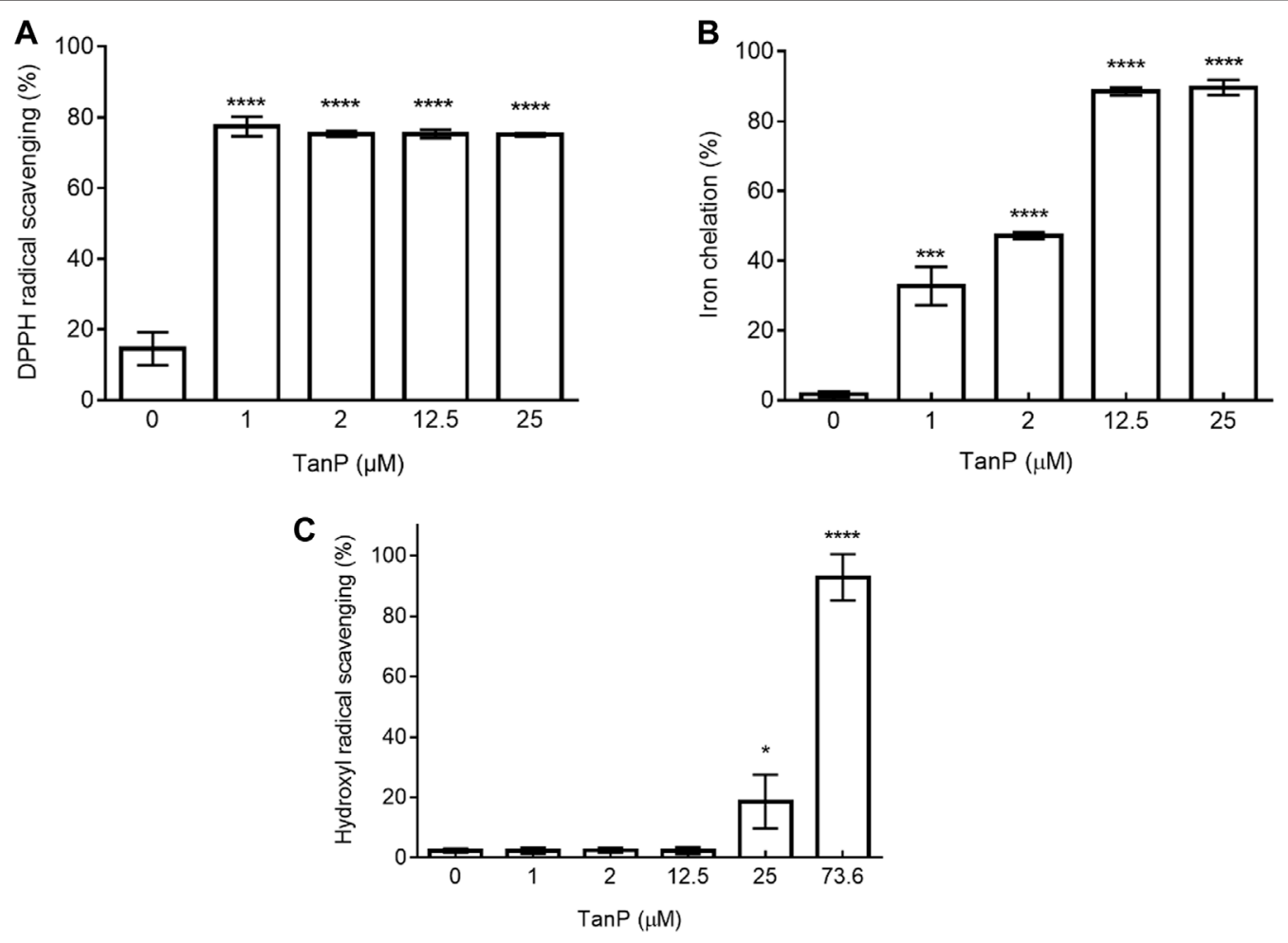

FIGURE 4 | Evaluation of antioxidant activity of TanP. (A) DPPH radical scavenging capacity. DPPH solution (150 $\mu$ M) was used as a control. (B) Iron chelation capacity. EDTA $(0.1 \mathrm{mg} / \mathrm{ml})$ was used as a control. (C) Hydroxyl radical scavenging activity of TanP. Gallic acid $(0.25-2 \mathrm{mg} / \mathrm{ml})$ was used as the control. Statistical significance was performed using ANOVA followed by Tukey's test and expressed as mean $\pm \mathrm{SD}(\mathrm{n}=3) .{ }^{*} p<0.05,{ }^{* *} p<0.01,{ }^{* \star *} p<0.001$, and ${ }^{* * * *} p<0.0001$ compared with the control group.

$\%$ radical scavenging $=\left[\frac{(\text { absorbance of control }- \text { absorbance of sample })}{(\text { absorbance of control }- \text { absorbance of blank })}\right] \times 100$

\section{Iron-Chelating Assay}

The ability to chelate iron ions was assessed as previously described in the literature, with modifications (Wang et al., 2008). The samples of TanP $(1-25 \mu \mathrm{M})$ were added to the reaction solution $(2 \mathrm{mM} \mathrm{FeCl}$ and $5 \mathrm{mM}$ ferrozine) and incubated for $10 \mathrm{~min}$ at $37^{\circ} \mathrm{C}$. The absorbance was measured at $562 \mathrm{~nm}$. The chelating activity was expressed as the chelation percentage in relation to a blank (absence of sample). EDTA $(0.1 \mathrm{mg} / \mathrm{ml})$ was used as the positive control.

\section{Copper Chelation Assay}

The copper chelation test was performed as described previously (Presa et al., 2018). In brief, 96-well microplates with a reaction mixture containing different concentrations of TanP $(1-25 \mu \mathrm{M})$, pyrocatechol violet $(4 \mathrm{mM})$, and copper II sulfate pentahydrate $(50 \mathrm{mg} / \mathrm{ml})$ were homogenized with the aid of a micropipette, and the absorbance of the solution was measured at $632 \mathrm{~nm}$ using a microplate reader (SpectraMax ${ }^{\circledR}$ M2/M2e, Molecular Devices, São José, California, United States of America).

\section{Reducing Power Assay}

The reducing power of the samples was examined according to Presa et al. (2018). In brief, different sample concentrations
(1-25 $\mu \mathrm{M})$ were added to a solution of $200 \mathrm{mM}$ sodium phosphate buffer $(\mathrm{pH}$ 6.6) and potassium ferricyanide $(10 \mathrm{mg} / \mathrm{ml})$. After incubation in a water bath at $50^{\circ} \mathrm{C}$ for $20 \mathrm{~min}$, trichloroacetic acid $(10 \% \mathrm{w} / \mathrm{v})$ and iron III chloride $(0.1 \% \mathrm{w} / \mathrm{v})$ were added. The mixture was stirred, and the absorbance $(700 \mathrm{~nm})$ was measured using a microplate reader. The results were expressed as the percentage of activity observed for $0.1 \mathrm{mg} / \mathrm{ml}$ (highest activity) ascorbic acid.

\section{Determination of Anticoagulant Activity Prothrombin Time Test}

The action of TanP on the extrinsic coagulation pathway was evaluated by prothrombin time (PT) test, as previously described in the literature, with modifications (Félix-Silva et al., 2014). The test was carried out using commercial reagent kits (CLOT Bios Diagnostica ${ }^{\circledR}$, São Paulo, Brazil). The plasma $(70 \mu \mathrm{l})$ was mixed with $30 \mu$ of $\operatorname{TanP}(2,12.5$, and $25 \mu \mathrm{M})$ and incubated at $37^{\circ} \mathrm{C}$ for $5 \mathrm{~min}$. Then, $200 \mu \mathrm{l}$ of the PT assay reagent (rabbit brain extract and calcium chloride) pre-warmed at $37^{\circ} \mathrm{C}$ for $10 \mathrm{~min}$ was added, and the clotting time was recorded by a digital coagulometer ("Laser Sensor" Clotimer, CLOT, São Paulo, Brazil). Plasma alone (only with vehicle) was used as the control (in the absence of anticoagulant activity). The plasma with heparin $(1 \mathrm{IU} / \mathrm{ml})$ (Cristalia ${ }^{\circledR}$, São Paulo, Brazil) was used as the positive control. 

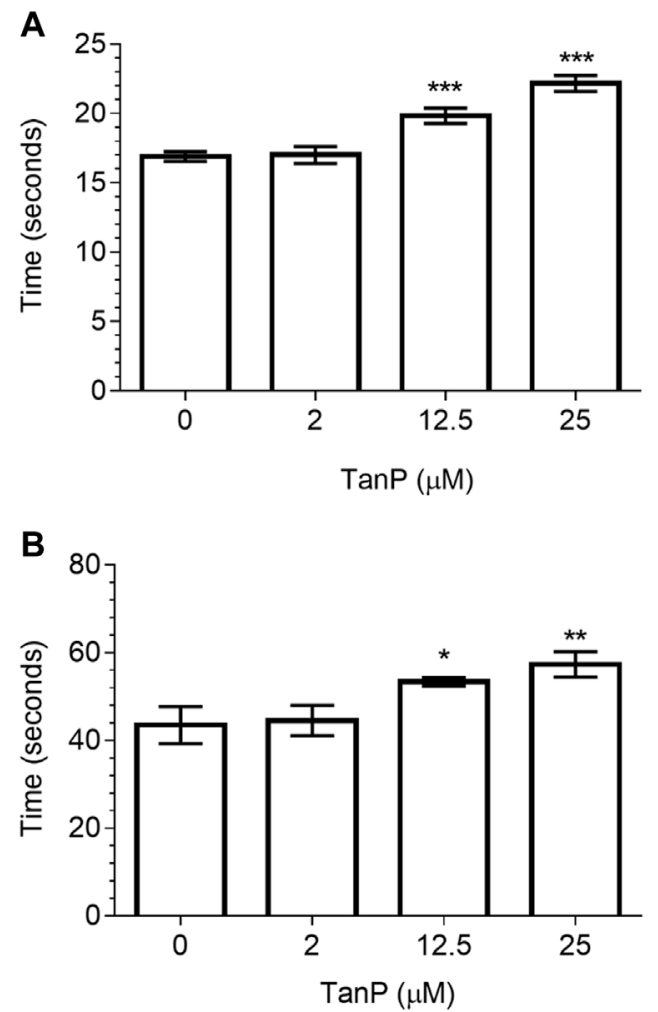

FIGURE 5 | Evaluation of TanP coagulant activity in vitro. (A) PT and (B) aPTT assays. Statistical significance was performed using ANOVA followed by Tukey's test and expressed as mean $\pm \operatorname{SD}(n=3)$. ${ }^{*} p<0.05$, ${ }^{* *} p<0.01$, and ${ }^{* \star *} p<0.001$, compared with the negative control group (plasma without TanP).

\section{Activated Partial Thromboplastin Time Test}

The action of TanP in intrinsic and common pathways of the coagulation cascade was evaluated by activated partial thromboplastin time (aPTT) assay, as previously described in the literature, with modifications (Félix-Silva et al., 2014). The test was carried out using commercial reagent kits (CLOT Bios Diagnostica). The plasma $(70 \mu \mathrm{l})$ was mixed with $30 \mu \mathrm{l}$ of TanP $(2,12.5$, and $25 \mu \mathrm{M})$ and incubated at $37^{\circ} \mathrm{C}$ for $5 \mathrm{~min}$. Then, $50 \mu$ l of the pre-warmed aPTT reagent (rabbit brain extract and ellagic acid) was added and incubated at $37^{\circ} \mathrm{C}$ for $3 \mathrm{~min}$. After incubation, pre-warmed $\left(37^{\circ} \mathrm{C}\right), 50 \mu \mathrm{l}$ of $25 \mathrm{mM}$ calcium chloride was added and the clotting time was recorded by a digital coagulometer ("Laser Sensor" Clotimer, CLOT). The plasma alone (only with the vehicle) was used as the control (in the absence of anticoagulant activity). The plasma with heparin (1 IU/ml) (Cristalia ${ }^{\circledR}$ ) was used as the positive control.

\section{Fibrinogenolytic Activity}

The effect of TanP on fibrinogen was evaluated by sodium dodecyl sulfate-polyacrylamide gel (SDS-PAGE) electrophoresis (Félix-Silva et al., 2014). The separation conditions were: voltage of $130 \mathrm{~V}$, amperage of $50 \mathrm{~mA}$, and
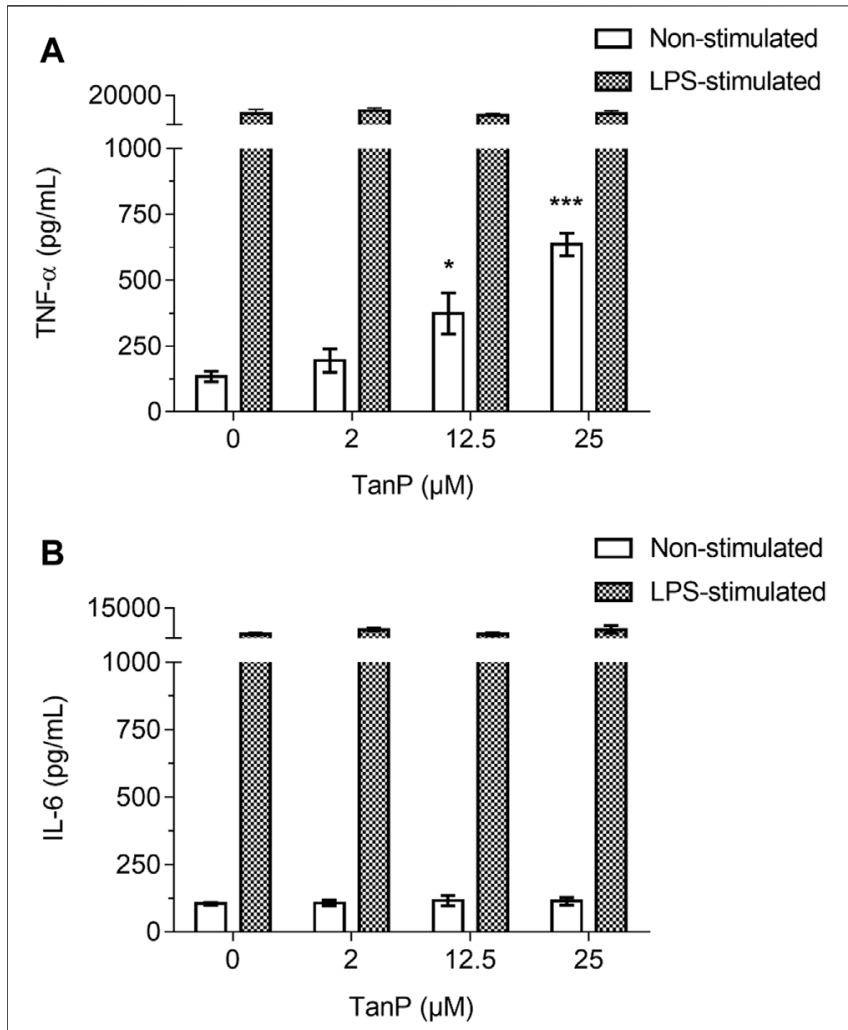

FIGURE 6 | Effect of TanP on pro-inflammatory cytokines levels in murine macrophage (RAW 264.7) supernatant. The release of cytokines (A) TNF- $\alpha$ and (B) IL-6 in the presence or absence of LPS. The levels of cytokines secretion by cells were measured for $24 \mathrm{~h}$ after the interaction with LPS $(2 \mu \mathrm{g} / \mathrm{ml})$ and/or at different concentrations of TanP $(0-25 \mu \mathrm{M})$. Statistical significance was performed using ANOVA followed by Tukey's test and expressed as mean $\pm \mathrm{SD}(\mathrm{n}=3) .{ }^{*} p<0.05$ and ${ }^{* *} p<0.001$, compared with the negative control group (cells without TanP or LPS) or the positive control group (cells only with LPS).

power of $90 \mathrm{~W}$. The different concentrations of TanP $(2-178 \mu \mathrm{M})$ were mixed with $50 \mu \mathrm{g}$ of the fibrinogen $(2 \mu \mathrm{g} / \mu \mathrm{l})$ and then incubated for $240 \mathrm{~min}$ at $37^{\circ} \mathrm{C}$. The reaction was stopped by adding $25 \mu \mathrm{l}$ of sample buffer containing $10 \% \beta$ mercaptoethanol and 2\% SDS, followed by boiling for $5 \mathrm{~min}$, and subjected to SDS-PAGE (12\%). The fibrinogen-hydrolyzing pattern was visualized by staining with Coomassie brilliant blue R-250. Fibrinogen alone was used as the control, for visualization of the intact fibrinogen profile. The Bothrops leucurus venom $(10 \mu \mathrm{g})$ was used as the positive control for the fibrinogenolytic activity. A sample containing only the peptide in the highest concentration $(178 \mu \mathrm{M})$ was used for control. Subsequently, the gel was digitized and the image was binarized to measure the area of one of the bands referring to fibrinogen degradation, using ImageJ 1.44p software (National Institutes of Health, Maryland, United States of America).

\section{In Vitro Immunomodulatory Activity}

Initially, TanP cytotoxicity by the 3-(4,5-dimethylthiazol-2-yl)2,5-diphenyltetrazolium bromide (MTT) reduction method to RAW 264.7 cells had been evaluated. The immunomodulatory 


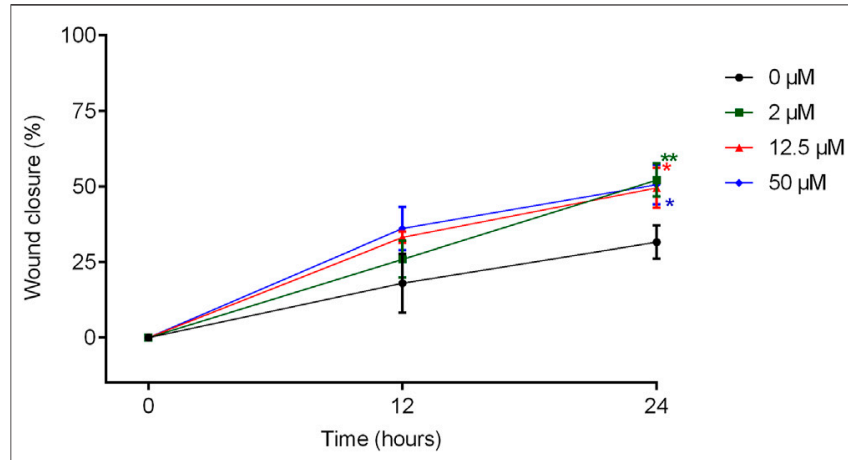

FIGURE 7 | Cell migration of 3T3 cells treated with TanP after the Scratch assay. Fibroblast confluence after scratching and treatment with different concentrations of $\operatorname{TanP}(0-50 \mu \mathrm{M})$ was analyzed at 0,12 , and $24 \mathrm{~h}$. The areas were measured with the aid of the software NIS-Elements AR. Statistical significance was performed using ANOVA followed by Tukey's test and expressed as mean $\pm \operatorname{SD}(n=3)$. ${ }^{*} p<0.05$ and ${ }^{* *} p<0.01$, compared with the control group (without TanP).

activity was evaluated by quantitation of IL- 6 and TNF cytokine levels in the TanP-treated RAW 264.7 macrophage culture supernatant in the presence and absence of LPS $(2 \mu \mathrm{g} / \mathrm{ml}$, from Escherichia coli, serotype O111:B4, Sigma-Aldrich ${ }^{\circledR}$, Saint Louis, United States of America). In 24-well microplates, the RAW 264.7 cells $\left(3 \times 10^{5}\right.$ cell/well $)$ were cultivated in Dulbecco's Modified Eagle Medium (DMEM) supplemented with 10\% fetal bovine serum (FBS) for $24 \mathrm{~h}$ at $37^{\circ} \mathrm{C}$ at an atmosphere of $5 \% \mathrm{CO}_{2}$. After this period, the medium was aspirated and TanP was added at different concentrations $(2-25 \mu \mathrm{M})$ in the absence or presence of LPS $(2 \mu \mathrm{g} / \mathrm{ml})$. The plate was maintained under the previously described conditions for $24 \mathrm{~h}$, and the culture medium was collected for cytokines level quantitation in the supernatant. The cytokines were quantified by ELISA using the eBioscience $^{\circledR}$ kit (San Diego, United States of America), following the methodology described by the manufacturer. The results were expressed in picograms per milliliter.

\section{Cell Viability of 3T3 Cells (ATCC CCL-92)}

The MTT assay was employed to assess the viability of 3T3 fibroblast cells (ATCC CCL-92) in the presence of TanP (Mosmann, 1983). The 3T3 cell line (ATCC CCL-92) was kindly provided by Dr. Carmen Ferreira (Department of Biochemistry, UNICAMP, São Paulo, Brazil). In brief, the 3T3 cells were seeded in a 96-well plate $\left(5 \times 10^{3}\right.$ cell/well $)$ and incubated in DMEM with $10 \% \mathrm{FBS}$, at $37^{\circ} \mathrm{C}$ with $5 \% \mathrm{CO}_{2}$ saturation. After this period, TanP was added at different concentrations $(5-50 \mu \mathrm{M})$ and incubated for $24 \mathrm{~h}$. Then, the peptide was removed, and $100 \mu \mathrm{l}$ of MTT $(5 \mathrm{mg} / \mathrm{ml})$ in medium was added and further incubated for $4 \mathrm{~h}$ at $37^{\circ} \mathrm{C}$. The supernatants were removed and replaced by $100 \mu \mathrm{l}$ of ethanol to solubilize formazan crystals. Measurements were carried out at $570 \mathrm{~nm}$ using the microplate reader (Epoch-BioTek ${ }^{\circledR}$ ). The results were presented as a percentage of MTT reduction, considering the absorbance of the negative control (plate without addition of the peptide) as $100 \%$ reduction.

\section{In Vitro Scratch Wound Assay}

The $3 \mathrm{~T} 3$ cells were seeded in a 24 -well plate and incubated in DMEM with $10 \%$ FBS until cell confluence reached about $80-90 \%$. The cells were further grown for the next $24 \mathrm{~h}$ at $37^{\circ} \mathrm{C}$ in a $5 \% \mathrm{CO}_{2}$ incubator. A uniform scratch wound was created using a 200 - $\mu$ l sterile pipette tip. To remove loose cells, the wells were washed with PBS ( $\mathrm{pH}, 7.4)$. The scratched cells were then treated with different concentrations of TanP $(2-50 \mu \mathrm{M})$. The wells containing only the culture medium were used as the negative control. To monitor the closure of the lesion, images were obtained using the Nikon Eclipse inverted microscope with a $10 \times$ objective, at 0,12 , and $24 \mathrm{~h}$, after incubation with TanP. The scratch area was analyzed using the software NIS-Elements AR, considering the results as a percentage of closure of the lesion in relation to the initial area (Balekar et al., 2012; Tonin et al., 2016).

\section{Statistical Analysis}

Statistical analysis was performed using GraphPad Prism software (version 7.0, GraphPad, San Diego, United States of America). All experiments were conducted at least in triplicates. The data analysis was performed using one-way analysis of variance (ANOVA) followed by Tukey's test. The data were expressed as mean \pm standard deviation (SD) and considered significant when $p<0.05,{ }^{* *} p<0.01,{ }^{* *} p<0.001$, and ${ }^{* * *} p<$ 0.0001 . For the experimental assay with metals, the program OriginPro 8.5 was used to plot the graphs.

\section{RESULTS}

\section{Metal-Chelating Properties of TanP}

The reactivity assays by UV-visible spectrometry of TanP with different concentrations of metal ions are reported in Figure 1. In the absence of metal ions, the UV-vis spectrum of TanP showed the absorption maximum at 255 and $275 \mathrm{~nm}$ (Supplementary Figure S1). When $\mathrm{FeSO}_{4} \cdot 7 \mathrm{H}_{2} \mathrm{O}$ was added, changes in the peptide spectral profile in maximum absorption from 255 to $275 \mathrm{~nm}$ occurred, indicating the formation of a TanP-Fe ${ }^{2+}$ complex. For $\mathrm{Zn}^{2+}$ no relevant spectral change was noted. As shown in Supplementary Figure S2, initially, in the presence of $\mathrm{Fe}^{2+}$, the absorbance increased linearly and then became stable, revealing a 1:5 stoichiometry for the complex (TanP: $\mathrm{Fe}^{2+}$ ).

To propose a mode of interaction of TanP with $\mathrm{Fe}^{2+}$ and $\mathrm{Zn}^{2+}$ ions, the following $\left[\mathrm{Fe}(\mathrm{Ac} .)_{2}\left(\mathrm{H}_{2} \mathrm{O}\right)_{4}\right]$ and $\left[\mathrm{Zn}(\mathrm{Ac} .)_{2}\left(\mathrm{H}_{2} \mathrm{O}\right)_{2}\right]$ complexes were used after conformational searching. The obtained geometries for $\mathrm{Zn}^{2+}$ and $\mathrm{Fe}^{2+}$ complexes presenting tetrahedral and octahedral shapes, respectively (Supplementary Figure S3). For $\mathrm{Zn}^{2+}$, two water molecules and one oxygen of each acetate are located on the vertices of a tetrahedral-like structure. The angles between these four ligands passing by the metallic central atom have an average of $108.7^{\circ}$, which characterizes this geometry, and an average distance of $2.0 \AA$. As on the $\mathrm{Zn}^{2+}$ complexes, dication iron also interacts with one oxygen of each acetate carboxylate; however, four water molecules are present on the first hydration shell and form an octahedral complex. The average angles between the adjacent and 
opposite oxygen atoms were $90.0^{\circ}$ and $174.5^{\circ}$, respectively, over an average distance of $2.0 \AA$ from the central atom.

Theoretical absorption spectra for the two $\left[\mathrm{Fe}(\mathrm{Ac} .)_{2}\left(\mathrm{H}_{2} \mathrm{O}\right)_{4}\right]$ and $\left[\mathrm{Zn}(\mathrm{Ac} \text {. })_{2}\left(\mathrm{H}_{2} \mathrm{O}\right)_{2}\right]$ complexes are displayed in Supplementary Figure S4. These spectra were simulated for the spectral range of wavelengths between 170 and $300 \mathrm{~nm}$, which is consistent with the spectral window used to obtain the experimental data (Supplementary Figure S1). All vertical transitions calculated for the two complexes are characterized (wavelength, oscillator strength, and types of orbitals involved in the transitions) and listed in the Supplementary Table S1. As can be observed in Supplementary Figure S4 and Supplementary Table S1, while the $\left[\mathrm{Zn}(\text { Ac. })_{2}\left(\mathrm{H}_{2} \mathrm{O}\right)_{2}\right]$ complex presents nine excited states (between 172 and $212 \mathrm{~nm}$ ), the $\left[\mathrm{Fe}(\mathrm{Ac} .)_{2}\left(\mathrm{H}_{2} \mathrm{O}\right)_{4}\right]$ complex has 20 excited states (between 171 and $255 \mathrm{~nm}$ ). The NTOs of the main excited state for the $\left[\mathrm{Fe}(\mathrm{Ac} .)_{2}\left(\mathrm{H}_{2} \mathrm{O}\right)_{4}\right]$ and $\left[\mathrm{Zn}(\mathrm{Ac} .)_{2}\left(\mathrm{H}_{2} \mathrm{O}\right)_{2}\right]$ complexes are displayed in Supplementary Figure S4.

On the one hand, these nine excited states of the [ $\mathrm{Zn}$ (Ac. $)_{2}\left(\mathrm{H}_{2} \mathrm{O}\right)_{2}$ ] complex are described mainly from transitions of the highest occupied molecular orbitals (HOMO, HOMO-1, and HOMO-2) centered on the carboxylate ligand (orbitals type $n$ ) to the lowest unoccupied molecular orbitals (LUMO, $\mathrm{LUMO}+1$, and LUMO+2) also associated with the acetate ligand moiety (type $\pi^{*}$ orbitals). On the other hand, for the [Fe $\left.(\text { Ac. })_{2}\left(\mathrm{H}_{2} \mathrm{O}\right)_{4}\right]$ complex, the most important excited states describe a low-intensity band (between 185 and $220 \mathrm{~nm}$ ), which results mainly from almost isoenergetic transitions originating from the $3 \mathrm{~d}$ orbitals (HOMO, HOMO-1, and HOMO-2) located at the metallic center to the type $\pi^{*}$ orbitals located at the acetate ligand (LUMO+3 and LUMO+4).

In fluorescence emission spectra, $\operatorname{Tan} P(1.12 \mu \mathrm{M})$ revealed an intense emission band with $\lambda_{\max }$ around $353 \mathrm{~nm}$ when excited at $285 \mathrm{~nm}$, which is in agreement with the tryptophan (Trp) emission range (Supplementary Figure S5). The fluorescence intensity of TanP $(1.12 \mu \mathrm{M})$ decreased after $\mathrm{Fe}^{2+}$ addition (Figure 2A). The highest ratio of 1:7.4 (TanP: $\mathrm{Fe}^{2+}$ ) led to the lowest fluorescence intensity, according to the value obtained in the graph regarding the spectral variations of the emission band as a function of the concentration of the metal ion (Figure 2B). No change in fluorescence emission of TanP was noted by the addition of $\mathrm{Zn}^{2+}$ (Supplementary Figure S6).

\section{Hemolytic Activity}

TanP showed low hemolytic activity for all concentrations tested $(1.56-50 \mu \mathrm{M})$, with $3 \%$ of hemolytic activity when evaluated at the highest concentration $(50 \mu \mathrm{M})$, evidencing that the peptide did not cause significant hemolysis effect in red blood cells in vitro (Figure 3).

\section{In Vitro Antioxidant Potential of TanP}

TanP showed low activity (less 5\%) in three different tests, reducing power, superoxide radical-scavenging, and copperchelating test (data not shown). On the other hand, TanP exhibited DPPH radical-scavenging activity above $70 \%$ at all concentrations (1-25 $\mu \mathrm{M})$ (Figure 4A). For the iron ion chelation test, TanP showed $89.7 \%$ activity (Figure $4 \mathbf{B}$ ) when evaluated at the highest concentration $(25 \mu \mathrm{M})$. In addition, TanP $(73.6 \mu \mathrm{M})$ displayed $96 \%$ of the hydroxyl radical-scavenging activity (Figure 4C).

\section{Evaluation Anticoagulant Activity In Vitro}

The anticoagulant activity of TanP was evaluated by the PT and aPTT assays, using normal citrated human plasma. In both assays, TanP revealed the anticoagulant effect at concentrations of 12.5 and $25 \mu \mathrm{M}$ (Figure 5). In the TP assay, a clotting time of 20 and $22.5 \mathrm{~s}$ was found for concentrations of 12.5 and $25 \mu \mathrm{M}$, respectively (Figure $\mathbf{5 A}$ ). In the aPTT assay, a clotting time of 53.4 and $58.4 \mathrm{~s}$ was found, for concentrations of 12.5 and $25 \mu \mathrm{M}$, respectively (Figure 5B). Plasma with heparin was used as the positive control and as expected presented significant anticoagulant activity, with PT higher than $60 \mathrm{~s}$ (seconds of the negative control: $16.27 \pm 0.32$ ) and aPTT higher than $240 \mathrm{~s}$ (seconds of the negative control: $35.07 \pm 0.03$ ).

In addition to the anticoagulant activity, TanP was also tested in relation to its capacity to hydrolyze fibrin and fibrinogen, in view of investigating its potentiality as a thrombolytic agent. At the concentrations evaluated, TanP did not demonstrate fibrinogenolytic activity (data not shown).

\section{Effect of TanP on the Release of Cytokines} TanP $(2-25 \mu \mathrm{M})$ did not reduce the viability of RAW 264.7 cells when incubated for $24 \mathrm{~h}$, indicating a nontoxic character for this cell line (Supplementary Figure S7). The peptide induced a distinct release profile of the pro-inflammatory cytokines TNF- $\alpha$ and IL- 6 in the absence of LPS. An increase in TNF- $\alpha$ expression of 316.26 and $622.56 \mathrm{pg} / \mathrm{ml}$ was observed in the supernatant of the murine macrophage culture in the presence of 12.5 and $25 \mu \mathrm{M}$ of TanP, respectively, revealing a concentration-dependent relationship (Figure 6A). No significant changes were observed for IL-6 levels (Figure 6B). In the presence of LPS, TanP $(2-25 \mu \mathrm{M})$ did not induce changes in the release profile of the TNF- $\alpha$ and IL- 6 cytokines when incubated for $24 \mathrm{~h}$.

\section{Cell Viability of 3T3 Cells}

TanP $(2-50 \mu \mathrm{M})$ neither induced the proliferation of 3T3 cells nor reduced their viability when incubated for $24 \mathrm{~h}$, indicating a nontoxic character for this cell line (Supplementary Figure S8).

\section{Evaluation of the Healing Potential of TanP Using Cell Migration Assay}

Figure 7 shows the effect of treatment with TanP at different concentrations $(2-50 \mu \mathrm{M})$, at times 0,12 , and $24 \mathrm{~h}$, with respect to the migration of fibroblasts, using the scratch method.

When the measurements of the scratch areas were compared, a significant increase in the percentage of lesion closure was observed after $24 \mathrm{~h}$ of incubation with the peptide, for all concentrations evaluated in relation to the group control. In addition, in the presence of $\operatorname{TanP}(2 \mu \mathrm{M}, 12.5$ and $50 \mu \mathrm{M})$, approximately $50 \%$ of the wound was closed after $24 \mathrm{~h}$ of treatment, whereas for the control group, this closure was only $30 \%$. 


\section{DISCUSSION}

High concentrations of $\mathrm{Fe}^{2+}$ and $\mathrm{Cu}^{2+}$ ions cause these metals to react with molecular oxygen, generating reactive oxygen species (ROS) that damage DNA, lipids, and proteins (Di Bella et al., 2017). Furthermore, cancer, diabetes, arteriosclerosis, inflammatory disease, autoimmunity, cardiovascular disease, and Alzheimer's disease have been associated with the increase of ROS or the inability of the organism to reduce these reactive species (Nascimento et al., 2013). The development of multifunctional molecules, including natural products, capable of simultaneously combating several pathological characteristics, acting as chelating agents, antioxidants, anti-inflammatories, and peptide aggregation reducers, among others, is considered a new perspective for the treatment of neurodegenerative diseases (Sales et al., 2019). In this context, components present in the scorpion venom have demonstrated anti-inflammatory (Veloso Júnior et al., 2019), chelating (Melo et al., 2017), and antioxidant action (Daniele-Silva et al., 2021), constituting a promising source for the development of new drugs.

In this study, TanP revealed a significant affinity on iron (II), a biologically important metal ion, not showing a similar affinity profile with respect to the zinc (II) metal, in the experimental conditions observed (Figure 1).

Complexation with $\mathrm{Fe}^{2+}$ ions is commonly related to obtaining a compound of octahedral geometry. Coordination sites involving sulfur, nitrogen, and oxygen donors promote this interaction (Bal et al., 2013; Antonietti et al., 2017). In the literature, it is suggested that the metal-binding sites in ironchelating peptides may also be the carboxyl groups of the aspartic and glutamic residues (Lv et al., 2009; Caetano-Silva et al., 2018), terminal amino and carboxylate groups, and the peptide bonds of the peptide structure, as well as the amino and arginine imine, lysine amino, and histidine imine. In addition, it was found that the absence of these amino acid residues in the peptide chain results in less iron-chelating potential (Wu et al., 2017). Thus, it is suggested that $\mathrm{Fe}^{2+}$ ions form a complex with TanP possibly by binding to the oxygen atoms of the carboxylate groups of the aspartic and glutamic acid side chains.

The tetrahedral geometry obtained for the $\left[\mathrm{Zn}(\text { Ac. })_{2}\left(\mathrm{H}_{2} \mathrm{O}\right)_{2}\right]$ complex in the computational assay of this study revealed a configuration commonly obtained for dication zinc complexes, mainly bio-complexes since the zinc ion interacts with donors such as oxygen and nitrogen of enzyme side chains to generate stronger complexes (Krezel and Maret, 2016). Regarding the geometry obtained for the $\left[\mathrm{Fe}(\mathrm{Ac} .)_{2}\left(\mathrm{H}_{2} \mathrm{O}\right)_{4}\right]$ complex, this is in accordance with several iron complexes that generate the octahedral shape on an aqueous medium, including biological molecules as the heme group (Poulos, 2014).

Our NBO analyses (Supplementary Figure S9, S10, and S11) indicate that while for the $\left[\mathrm{Fe}(\mathrm{Ac} .)_{2}\left(\mathrm{H}_{2} \mathrm{O}\right)_{4}\right]$ complex, the $3 \mathrm{~d}$ orbitals of the metallic center are set near the HOMO-LUMO frontier orbitals, for the $\left[\mathrm{Zn}(\mathrm{Ac} \text {. })_{2}\left(\mathrm{H}_{2} \mathrm{O}\right)_{2}\right]$ complex, the $3 \mathrm{~d}$ orbitals of zinc are far from the boundary orbitals. Then, considering the participation of the relevant molecular orbitals, for the $\left[\mathrm{Zn}(\mathrm{Ac} .)_{2}\left(\mathrm{H}_{2} \mathrm{O}\right)_{2}\right]$ complex, the excited states can be assigned mainly as transitions involving just orbitals of aspartate ligand. Differently, for the $\left[\mathrm{Fe}(\mathrm{Ac} .)_{2}\left(\mathrm{H}_{2} \mathrm{O}\right)_{4}\right]$ complex, the main absorption band can be assigned mainly as a metal-toligand charge transfer. These theoretical results suggest that by UV-vis spectroscopy: 1) TanP can work as a sensor to identify and quantify (at the evaluated concentrations) iron (II) ions; and 2) TanP does not seem to have sensibility for bivalent zinc (at the evaluated concentrations and spectral range considered).

Conformational changes of proteins can be monitored using fluorescent probes or intrinsic fluorescence, which is caused by aromatic amino acid residues (tryptophan, tyrosine, and phenylalanine) (Zhdanova et al., 2015). In the primary sequence, TanP contains one tyrosine residue, three phenylalanine residues, and one tryptophan residue, which contribute to the intrinsic fluorescence of the peptide.

When evaluated by fluorescence spectroscopy, TanP displayed an intense emission band with $\lambda_{\max }$ around $353 \mathrm{~nm}$, when excited at $285 \mathrm{~nm}$ (Supplementary Figure S5), which corroborates with the maximum emission length of tryptophan, which varies from 310 to $350 \mathrm{~nm}$, depending on the electrostatic environment (Adams et al., 2002). For the other chromophores, tyrosine and phenylalanine amino acids, the emission spectrum is in the $290 \mathrm{~nm}$ range, which overlaps with the absorption spectrum of tryptophan, causing an energy transfer from these amino acids to tryptophan, making this the dominant chromophore in the fluorescence process of peptides and proteins (Zhdanova et al., 2015).

The changes observed in TanP emission bands, in the presence of $\mathrm{Fe}^{2+}$, corroborate with the results obtained in UV-vis spectroscopy. The lower concentration of $\operatorname{TanP}(1.12 \mu \mathrm{M})$ coordinates more iron ions, 1:7.4 (TanP: $\left.\mathrm{Fe}^{2+}\right)$. A similar proportion (TanP:metal) was reported in the UV-vis copper study, for a peptide concentration of $2.11 \mu \mathrm{M}$, mentioning a proportion of 1:7 (TanP: $\mathrm{Cu}^{2+}$ ) (Melo et al., 2017). In addition, it can be suggested that the metal is binding to a site close to the amino acid tryptophan.

The presence of molecules with antioxidant effects in scorpions has been reported in the literature (Wali et al., 2020). The Stigmurin (FFSLIPSLVGGLISAFK-NH2), cationic peptide of $T$. stigmurus, showed hydroxyl radical scavenging above $70 \%$ at $10 \mu \mathrm{M}$ (Daniele-Silva et al., 2021). A peptide fraction isolated from the venom of Buthus occitanus has been demonstrated to exhibit the antioxidant and free radical scavenger effects (Bekheet et al., 2013). Antioxidant peptides from B. martensii Karsch were separated and purified, and showed the highest $\mathrm{ABTS}^{+}$-scavenging activity and the highest $\mathrm{DPPH}$-scavenging activity, but the $\mathrm{OH}$-scavenging activities of these peptides were not significant (Wali et al., 2020).

The substrate oxidation process consists of three stages (initiation, propagation, and termination). Antioxidants can act at any of these steps, and the more steps a compound intervenes at, the better the antioxidant it is (Wali et al., 2020). Several in vitro antioxidant tests are available to assess the antioxidant activity of biomolecules (Gulcin, 2020). In this current study, we used six methods to evaluate the possible effect of TanP on the initiation (DPPH, iron, and copper chelation), propagation (reducing power), and termination (superoxide and hydroxyl radical-scavenging activities) steps. 
In this approach, TanP revealed significant iron-chelating activity, reaching up to above $90 \%$ of chelation (Figure 4B), being a pioneer in demonstrating the antioxidant potential of anionic peptides present in the scorpion venom. Chelation of metal iron has an antioxidant effect because the transition metal iron, just like copper, catalyzes the generation of ROS, including hydroxyl radical and superoxide radical, leading to the oxidation of unsaturated lipids and promoting oxidative damage at different levels (Nascimento et al., 2013).

Among ROS, the hydroxyl radical is the most reactive in chemistry. It can abstract hydrogen atoms from biological thiol molecules and form sulfur radicals capable of combining with oxygen to generate oxysulfur radicals and damage biological molecules (Singh and Singh, 2008; Melo-Silveira et al., 2012).

Overall, TanP revealed an antioxidant effect in two different stages of substrate oxidation process; initiation (DPPH reduction and ion chelation) and termination (hydroxyl radical scavenging) (Figure 4).

Different amino acid residues may be responsible for the antioxidant activity in peptides, which is usually due to chelation of transition metals and scavenging of free radicals (Carrasco-Castilla et al., 2012). The high content of hydrophobic amino acids in peptides was mainly responsible for the antioxidant activity (Wali et al., 2020). In addition, nucleophilic sulfur-containing side chains in cysteine and methionine residues, and aromatic side chains in tryptophan, tyrosine, and phenylalanine residues can easily donate hydrogen atoms (Carrasco-Castilla et al., 2012). In its composition, TanP has 23 hydrophobic residues, including one tyrosine, one tryptophan, and four phenylalanine.

Many animal venoms have shown the ability to act on the human hemostatic system as procoagulant or anticoagulant agents (Brazón et al., 2009). In this study, TanP was able to prolong the clotting time in PT and aPTT tests in the highest concentrations (Figure 5), demonstrating anticoagulant activity.

Some scorpion venoms cause blood clotting disorders, but the number of coagulopathic compounds studied to date is quite less (Félix-Silva et al., 2014). Dipeptides isolated from Heterometrus laoticus scorpion venom showed no anticoagulant activity at concentrations up to $100 \mu \mathrm{M}$ in PT and aPTT tests with the human plasma, but they strongly prolonged the bleeding time from mouse tail and in in vitro clot formation, through the inhibition of platelet aggregation (Tran et al., 2017).

Discreplasminin, a peptide isolated from Tityus discrepans venom, showed antifibrinolytic activity, since it inhibits plasmin; although, a previous study had shown the prolongation of human plasma PT and aPTT in the presence of the venom (Brazón et al., 2009). The hydrolyzate from the BmK protein of scorpion (B. martensii Karsch) exhibited high anticoagulant activity, and this action has been associated with the presence of negatively charged amino acids and hydrophobic residues (Ren et al., 2014).

Additionally, TanP did not demonstrate the ability to hydrolyze fibrinogen in tested concentrations. Differently from the results obtained in this study, it was identified in T. discrepans that fibrinogenolytic enzymes are responsible for the degradation of the fibrinogen $A \alpha$ and $B \beta$ chains, and these mechanisms were also related to the prolongation of $\mathrm{TP}$ and activated aPTT produced by the venom of T. discrepans (Brazón et al., 2014), demonstrating that components present in scorpion venom can induce a wide variability of effects on hemostasis.

Our results suggest that the observed anticoagulant activity may be due to an inhibitory action upon clotting factors. Another hypothesis for the observed anticoagulant action is that the possible target of peptide intervention may be platelet aggregation, since peptides isolated from scorpions have this mechanism already elucidated (Thien et al., 2017).

Although other scorpion venom peptides with anticoagulant activity are described in the literature, this is the first study that demonstrates that anionic peptides present in scorpion venom have this activity. However, given the results that have been presented, further studies are necessary to elucidate the exact mechanism of the anticoagulant effects of TanP.

Venoms and toxins are responsible for modulating the immune response (Petricevich, 2002; Petricevich and Lebrun, 2005). Envenoming by different species of scorpion, even the Tityus genus, results in the release of pro- and anti-inflammatory cytokines, and the balance between such cytokines in the poisoning determines the degree and extent of inflammation, which can lead to important clinical effects, such as cardiac dysfunction, pulmonary edema, and shock (Petricevich, 2010).

The macrophages are cells that participate in all stages of the inflammatory process, since phagocytosis helps in the production of chemokines, cytokines, and growth factors. In addition, the macrophages present extensive phenotypic and functional plasticity, whose regulation critically defines beneficial or detrimental outcomes in inflammatory responses (Mendes et al., 2019). TanP promoted the release of TNF- $\alpha$, in murine macrophages, in the absence of LPS (Figure 6A). It is not known whether stimulation of TNF- $\alpha$ cytokine production arises from a nonspecific interaction of the peptide with the macrophage membrane or from interaction with a specific receptor. However, TanP is unlikely to bind to the LPS receptor since the effects of LPS on cytokine production were not affected in the presence of the peptide.

Previous studies with $T$. serrulatus scorpion venom (TSV) demonstrated that the incubation of macrophages with TSV provided an increase in the production of IL- 6 and IFN- $\gamma$, but there was no detection of TNF- $\alpha$ in the cell supernatant (Petricevich, 2002). However, when evaluating the activity of fractions isolated from this venom, it was found that the FII fraction is a potent activator of the production of macrophage TNF- $\alpha$ (Petricevich and Lebrun, 2005).

Basic amino acids present in the peptide chain are important residues for interaction with the target in macrophages. Cationic peptides isolated from $T$. serrulatus venom were able to modulate macrophage responses, increasing the release of IL-6 (Pucca et al., 2016). ToAP3 and ToAP4, cationic peptides obtained from $T$. obscurus venom, have been demonstrated to be a potential in vitro immunomodulator on murine bone marrow-derived macrophages stimulated by LPS, being able to reduce the release of TNF- $\alpha$. This stimulation is associated with peptide interaction with toll-like receptor 4 (TLR4). However, no increase in cytokine levels was observed when both cells were treated with ToAP3 or ToAP4 alone (Veloso Júnior et al., 2019). Although 
TanP had no basic amino acid residues in its composition and was rich in acidic and hydrophobic residues, it was able to modulate cytokine release by macrophages in the absence of LPS. In murine macrophages, the LPS binds with a carrier of LPSbinding protein (LBP). The LPS-LBP complex interacts with some receptors such as CD14, MD2, and TLR-4 proteins that trigger the activation of an intracellular cascade that induces the activation of the transcription factor nuclear factor kappa $B$ to the nucleus, which is responsible for the transcription of proinflammatory genes, resulting in the production of inflammatory cytokines and the expression of co-stimulatory molecules (Torres-Rêgo et al., 2016; Zamyatina and Heine, 2020). The mechanism involved in the immunomodulatory effect by TanP is still unclear, and more tests should be carried out for elucidation. However, it is possible that TanP interacts with TLR4, inducing the production of TNF- $\alpha$. This interaction is significantly less than the power of the receptor to recognize LPS, so the presence of the peptide does not interfere with the activation caused by LPS.

The release of nitrite by RAW macrophages in the presence of LPS was inhibited by TanP, indicating that the peptide neutralizes LPS-induced nitric oxide production. TanP treatment without LPS stimulation reached the same level as the negative control (Melo et al., 2017). Thus, it is suggested that TanP has an immunomodulatory potential because in unstimulated macrophages, it can increase the release of inflammatory mediators, while in the presence of LPS, it decreases the production of nitric oxide, thus preventing exacerbated inflammatory reactions. There are a few studies involving the immunomodulatory potential of anionic peptides. To date, no studies with anionic peptide from scorpion venom in the approach of the immunomodulatory activity are known.

Considering a skin lesion, wound healing after hemostasis occurs in three overlapping stages: inflammation, proliferation, and remodeling. Fibroblasts are critical in all the three phases (Desjardins-Park et al., 2018). Fibroblast migration can accelerate the wound's revitalization process and promote its closure during healing (Liu et al., 2014; Yang et al., 2019).

In this study, it was demonstrated that TanP $(2-50 \mu \mathrm{M})$ does not exhibit the potential to promote the proliferation of 3T3 cells in vitro, but a significant increase in the percentage of lesion closure was observed after $24 \mathrm{~h}$ of incubation with the peptide in certain concentrations, due to the action on fibroblast migration (Figure 7). Thus, it is suggested that TanP may be acting as an exogenous fibroblast growth factor, or it may potentiate the activity of existing fibroblast growth factors.

Chronic wounds contain high levels of reactive oxygen and nitrogen species. The overproduction of free radicals, together with the accumulation of iron ions, perpetuates the inflammatory phase, resulting in severe tissue damage. For this reason, the introduction of antioxidants seems to be a promising strategy to promote normal wound healing (Pivec et al., 2019).

Iron-chelating molecules, such as deferoxamine, have high wound healing potential, even when dealing with diabetic patients, suggesting that iron depletion is beneficial in endothelial dysfunction in diabetes (Duscher et al., 2018). Thus, as TanP was able to chelate iron ions, there is a perspective that this function may contribute to the wound healing process.

In the inflammation process, at the initial healing stage, excessive inflammatory mediators, such as radicals, are released at the wound site, often associated with oxidative stress and subsequent prolonged inflammation, resulting in difficulty in healing the wound (Zhao et al., 2019). Therefore, since TanP also showed significant results with respect to chelating and antioxidant properties, and anti-inflammatory capacity, this peptide presents a high potential to be applied as a prototype to obtain new healing agents.

This is the first study to approach the role of anionic peptides of scorpions in immunomodulation and the wound healing process. Furthermore, TanP displayed the ability to chelate $\mathrm{Fe}^{2+}$ ions and revealed antioxidant and anticoagulant potential. This approach provides preliminary results regarding the therapeutic potential of TanP, which serve as a basis for the development of new studies in search of a prototype of a new drug. Besides, TanP has a potential for biotechnological application and can be used as a biosensor for identifying and quantifying $\mathrm{Fe}^{2+}$ ions.

\section{DATA AVAILABILITY STATEMENT}

The data sets presented in this study can be found in online repositories. The names of the repository/repositories and accession number(s) can be found in the article/ Supplementary Material.

\section{AUTHOR CONTRIBUTIONS}

MM was responsible for conceptualization, methodology, formal analysis, investigation, writing-original draft, and visualization. VO conducted the methodology, formal analysis, and writing-review and editing. MQ performed the methodology, formal analysis, and writing - review and editing. WP performed the methodology, formal analysis, and writing-review and editing. MT-R was responsible for writing-review and editing. SRBS performed the methodology, formal analysis, and writing-review and editing. DP conducted the formal analysis and writing-review and editing. HR realized the formal analysis and writing-review and editing. MS was responsible for methodology, formal analysis, and writing-review and editing. AS-J was responsible for resources and writing-review and editing. MF-P was responsible for conceptualization, methodology, writing-review and editing, supervision, project administration, and funding. All authors contributed equally toward the elaboration of the manuscript and have given their approval of the final version.

\section{FUNDING}

This study was financed in part by the Coordenação de Aperfeiçoamento de Pessoal de Nível Superior - Brasil (CAPES) - Finance Code 001 and CAPES - Toxinology 063/2010. 


\section{ACKNOWLEDGMENTS}

The authors acknowledge support from Conselho Nacional de Desenvolvimento Científico e Tecnológico (CNPq). The authors thank the High-Performance Computing Center at UFRN (NPAD/UFRN) for the computer cluster facility. The authors would like to thank the Department of Biochemistry of UFRN for allowing us to use the facilities of the cell culture room. The authors are also grateful to Glenn Hawes, M Ed. (Master of

\section{REFERENCES}

Adams, P. D., Chen, Y., Ma, K., Zagorski, M. G., Sönnichsen, F. D., McLaughlin, M. L., et al. (2002). Intramolecular Quenching of Tryptophan Fluorescence by the Peptide Bond in Cyclic Hexapeptides. J. Am. Chem. Soc. 124, 9278-9286. doi:10.1021/ja0167710

Almaaytah, A., Tarazi, S., Mhaidat, N., Al-Balas, Q., and Mukattash, T. L. (2013). Mauriporin, a Novel Cationic a-Helical Peptide with Selective Cytotoxic Activity against Prostate Cancer Cell Lines from the Venom of the Scorpion Androctonus Mauritanicus. Int. J. Pept. Res. Ther. 19, 281-293. doi:10.1007/ s10989-013-9350-3

Almeida, D. D., Scortecci, K. C., Kobashi, L. S., Agnez-Lima, L. F., Medeiros, S. R. B., Silva-Junior, A. A., et al. (2012). Profiling the Resting Venom Gland of the Scorpion Tityus Stigmurus through a Transcriptomic Survey. BMC Genomics 13, 362. doi:10.1186/1471-2164-13-362

Alvarenga, E. R., Mendes, T. M., Magalhaes, B. F., Siqueira, F. F., Dantas, A. E., Barroca, T. M., et al. (2012). Transcriptome Analysis of the Tityus Serrulatus Scorpion Venom Gland. OJGen 02, 210-220. doi:10.4236/ ojgen.2012.24027

Andersen, O. (2004). Chemical and Biological Considerations in the Treatment of Metal Intoxications by Chelating Agents. Mrmc 4, 11-21. doi:10.2174/ 1389557043487583

Antoniades, V., Sioga, A., Dietrich, E. M., Meditskou, S., Ekonomou, L., and Antoniades, K. (2013). Is Copper Chelation an Effective Anti-angiogenic Strategy for Cancer Treatment? Med. Hypotheses 81, 1159-1163. doi:10.1016/j.mehy.2013.09.035

Antonietti, V., Boudesocque, S., Dupont, L., Farvacques, N., Cézard, C., Da Nascimento, S., et al. (2017). Synthesis, Iron(III) Complexation Properties, Molecular Dynamics Simulations and P. aeruginosa Siderophore-like Activity of Two Pyoverdine Analogs. Eur. J. Med. Chem. 137, 338-350. doi:10.1016/ j.ejmech.2017.06.010

Bal, W., Sokołowska, M., Kurowska, E., and Faller, P. (2013). Binding of Transition Metal Ions to Albumin: Sites, Affinities and Rates. Biochim. Biophys. Acta (Bba) - Gen. Subjects 1830, 5444-5455. doi:10.1016/j.bbagen.2013.06.018

Balekar, N., Katkam, N. G., Nakpheng, T., Jehtae, K., and Srichana, T. (2012). Evaluation of the Wound Healing Potential of Wedelia Trilobata (L.) Leaves. J. Ethnopharmacol. 141, 817-824. doi:10.1016/j.jep.2012.03.019

Bannwarth, C., Caldeweyher, E., Ehlert, S., Hansen, A., Pracht, P., Seibert, J., et al. (2021). Extended Tight-binding Quantum Chemistry Methods. Wires Comput. Mol. Sci. 11, 1-49. doi:10.1002/wcms.1493

Baradaran, M., Jalali, A., Naderi-Soorki, M., Jokar, M., and Galehdari, H. (2018). First Transcriptome Analysis of Iranian Scorpion, Mesobuthus Eupeus Venom Gland. Iran. J. Pharm. Res. 17, 1488-1502. doi:10.22037/ijpr.2018.2300

Becke, A. D. (1988). Density-functional Exchange-Energy Approximation with Correct Asymptotic Behavior. Phys. Rev. A. 38, 3098-3100. doi:10.1103/ PhysRevA.38.3098

Bekheet, S. H. M., Awadalla, E. A., Salman, M. M., and Hassan, M. K. (2013). Prevention of Hepatic and Renal Toxicity with Bradykinin Potentiating Factor (BPF) Isolated from Egyptian Scorpion Venom (Buthus Occitanus) in Gentamicin Treated Rats. Tissue and Cell 45, 89-94. doi:10.1016/ j.tice.2012.09.006

Ben-Shushan, S., and Miller, Y. (2021). Neuropeptides: Roles and Activities as Metal Chelators in Neurodegenerative Diseases. J. Phys. Chem. B 125, 2796-2811. doi:10.1021/acs.jpcb.0c11151
English Education, University of Georgia) for editing the manuscript.

\section{SUPPLEMENTARY MATERIAL}

The Supplementary Material for this article can be found online at: https://www.frontiersin.org/articles/10.3389/fmolb.2021.785316/ full\#supplementary-material

Brazón, J., D’Suze, G., D’Errico, M. L., Arocha-Piñango, C. L., and Guerrero, B. (2009). Discreplasminin, a Plasmin Inhibitor Isolated from Tityus Discrepans Scorpion Venom. Arch. Toxicol. 83, 669-678. doi:10.1007/s00204-008-0377-8

Brazón, J., Guerrero, B., D’Suze, G., Sevcik, C., and Arocha-Piñango, C. L. (2014). Fibrin(ogen)olytic Enzymes in Scorpion (Tityus Discrepans) Venom. Comp. Biochem. Physiol. B: Biochem. Mol. Biol. 168, 62-69. doi:10.1016/ j.cbpb.2013.11.007

Caetano-Silva, M. E., Rund, L. A., Vailati-Riboni, M., Pacheco, M. T. B., and Johnson, R. W. (2021). Copper-Binding Peptides Attenuate Microglia Inflammation through Suppression of NF-kB Pathway. Mol. Nutr. Food Res. 65, 2100153-2100232. doi:10.1002/mnfr.202100153

Caetano-Silva, M. E., Alves, R. C., Lucena, G. N., Frem, R. C. G., Bertoldo-Pacheco, M. T., Lima-Pallone, J. A., et al. (2017). Synthesis of Whey Peptide-Iron Complexes: Influence of Using Different Iron Precursor Compounds. Food Res. Int. 101, 73-81. doi:10.1016/j.foodres.2017.08.056

Caetano-Silva, M. E., Cilla, A., Bertoldo-Pacheco, M. T., Netto, F. M., and Alegría, A. (2018). Evaluation of In Vitro Iron Bioavailability in Free Form and as Whey Peptide-Iron Complexes. J. Food Compost. Anal. 68, 95-100. doi:10.1016/ j.jfca.2017.03.010

Carrasco-Castilla, J., Hernández-Álvarez, A. J., Jiménez-Martínez, C., JacintoHernández, C., Alaiz, M., Girón-Calle, J., et al. (2012). Antioxidant and Metal Chelating Activities of Peptide Fractions from Phaseolin and Bean Protein Hydrolysates. Food Chem. 135, 1789-1795. doi:10.1016/ j.foodchem.2012.06.016

Cesa-Luna, C., Muñoz-Rojas, J., Saab-Rincon, G., Baez, A., Morales-García, Y. E., Juárez-González, V. R., et al. (2019). Structural Characterization of Scorpion Peptides and Their Bactericidal Activity against Clinical Isolates of MultidrugResistant Bacteria. PLoS One 14, e0222438. doi:10.1371/journal.pone.0222438

Croney, J. (2001). Fluorescence Spectroscopy in Biochemistry: Teaching Basic Principles with Visual Demonstrations. Biochem. Mol. Biol. Educ. 29, 60-65. doi:10.1016/S1470-8175(01)00019-4

D’Suze, G., Rosales, A., Salazar, V., and Sevcik, C. (2010). Apoptogenic Peptides from Tityus Discrepans Scorpion Venom Acting against the SKBR3 Breast Cancer Cell Line. Toxicon 56, 1497-1505. doi:10.1016/j.toxicon.2010.09.008

Daniele-Silva, A., Machado, R. J. A., Monteiro, N. K. V., Estrela, A. B., Santos, E. C. G., Carvalho, E., et al. (2016). Stigmurin and TsAP-2 from Tityus Stigmurus Scorpion Venom: Assessment of Structure and Therapeutic Potential in Experimental Sepsis. Toxicon 121, 10-21. doi:10.1016/j.toxicon.2016.08.016

Daniele-Silva, A., Rodrigues, S. d. C. S., dos Santos, E. C. G., Queiroz Neto, M. F. d., Rocha, H. A. d. O., Silva-Júnior, A. A. d., et al. (2021). NMR Three-Dimensional Structure of the Cationic Peptide Stigmurin from Tityus Stigmurus Scorpion Venom: In Vitro Antioxidant and In Vivo Antibacterial and Healing Activity. Peptides 137, 170478. doi:10.1016/j.peptides.2020.170478

de Menezes, Y. A., Félix-Silva, J., da Silva-Júnior, A., Rebecchi, I., de Oliveira, A., Uchoa, A., et al. (2014). Protein-rich Fraction of Cnidoscolus Urens (L.) arthur Leaves: Enzymatic Characterization and Procoagulant and Fibrinogenolytic Activities. Molecules 19, 3552-3569. doi:10.3390/molecules19033552

de Oliveira, U. C., Candido, D. M., Coronado Dorce, V. A., and Junqueira-de-Azevedo, I. d. L. M. (2015). The Transcriptome Recipe for the Venom Cocktail of Tityus Bahiensis Scorpion. Toxicon 95, 52-61. doi:10.1016/j.toxicon.2014.12.013

de Oliveira, U. C., Nishiyama, M. Y., dos Santos, M. B. V., Santos-Da-Silva, A. d. P., Chalkidis, H. d. M., Souza-Imberg, A., et al. (2018). Proteomic Endorsed Transcriptomic Profiles of Venom Glands from Tityus Obscurus and T. Serrulatus Scorpions. PLoS One 13, e0193739-23. doi:10.1371/ journal.pone.0193739 
Desjardins-Park, H. E., Foster, D. S., and Longaker, M. T. (2018). Fibroblasts and Wound Healing: an Update. Regenerative Med. 13, 491-495. doi:10.2217/rme-2018-0073

Di Bella, L. M., Alampi, R., Biundo, F., Toscano, G., and Felice, M. R. (2017). Copper Chelation and Interleukin-6 Proinflammatory Cytokine Effects on Expression of Different Proteins Involved in Iron Metabolism in HepG2 Cell Line. BMC Biochem. 18, 1-11. doi:10.1186/s12858-017-0076-2

Duscher, D., Januszyk, M., Maan, Z. N., Whittam, A. J., Hu, M. S., Walmsley, G. G., et al. (2018). Comparison of the Hydroxylase Inhibitor DMOG and the Iron Chelator Deferoxamine in Diabetic and Aged Wound Healing. HHS Public Access 139, 1-18. doi:10.1097/PRS.0000000000003072.Comparison

Félix-Silva, J., Souza, T., Camara, R. B. B. G., Cabral, B., Silva-Júnior, A. A., Rebecchi, I. M. M., et al. (2014). In Vitro anticoagulant and Antioxidant Activities of Jatropha Gossypiifolia L. (Euphorbiaceae) Leaves Aiming Therapeutical Applications. BMC Complement. Altern. Medaltern. Med. 14, 1-13. doi:10.1186/1472-6882-14-405

Flora, S. J. S., and Pachauri, V. (2010). Chelation in Metal Intoxication. Ijerph 7, 2745-2788. doi:10.3390/ijerph7072745

Foster, J. P., and Weinhold, F. (1980). Natural Hybrid Orbitals. J. Am. Chem. Soc. 102, 7211-7218. doi:10.1021/ja00544a007

Frisch, M. J., Trucks, G. W., Schlegel, H. B., Scuseria, G. E., Robb, M. A., Cheeseman, J. R., et al. (2016). Gaussian 16, Revision C.01. Wallingford CT: Gaussian, Inc. doi:10.1016/j.jinorgbio.2012.04.008

Furtado, A. A., Daniele-Silva, A., Silva-Júnior, A. A. d., Fernandes-Pedrosa, M. d. F., Marco, M., Deyou, T., et al. (2020). Biology, Venom Composition, and Scorpionism Induced by Brazilian Scorpion Tityus Stigmurus (Thorell, 1876) (Scorpiones: Buthidae): A Mini-Review. Toxicon 185, 36-45. doi:10.1016/ j.toxicon.2020.06.015

Gao, B., Xu, J., del Carmen Rodriguez, M., Lanz-Mendoza, H., Hernández-Rivas, R., Du, W., et al. (2010). Characterization of Two Linear Cationic Antimalarial Peptides in the Scorpion Mesobuthus Eupeus. Biochimie 92, 350-359. doi:10.1016/j.biochi.2010.01.011

Grimme, S. (2019). Exploration of Chemical Compound, Conformer, and Reaction Space with Meta-Dynamics Simulations Based on Tight-Binding Quantum Chemical Calculations. J. Chem. Theor. Comput. 15, 2847-2862. doi:10.1021/ acs.jctc. $9 \mathrm{~b} 00143$

Guilhelmelli, F., Vilela, N., Smidt, K. S., de Oliveira, M. A., da Cunha Morales Álvares, A., Rigonatto, M. C. L., et al. (2016). Activity of Scorpion VenomDerived Antifungal Peptides against Planktonic Cells of Candida Spp. And Cryptococcus Neoformans and Candida Albicans Biofilms. Front. Microbiol. 7, 1-14. doi:10.3389/fmicb.2016.01844

Gulcin, I. (2020). Antioxidants and Antioxidant Methods: an Updated Overview. Arch. Toxicol. 94, 651-715. doi:10.1007/s00204-020-02689-3

Guo, X., Ma, C., Du, Q., Wei, R., Wang, L., Zhou, M., et al. (2013). Two Peptides, TsAP-1 and TsAP-2, from the Venom of the Brazilian Yellow Scorpion, Tityus Serrulatus: Evaluation of Their Antimicrobial and Anticancer Activities. Biochimie 95, 1784-1794. doi:10.1016/j.biochi.2013.06.003

Krężel, A., and Maret, W. (2016). The Biological Inorganic Chemistry of Zinc Ions. Arch. Biochem. Biophys. 611, 3-19. doi:10.1016/j.abb.2016.04.010

Lai, R., Liu, H., Hui Lee, W., and Zhang, Y. (2002). An Anionic Antimicrobial Peptide from Toad Bombina Maxima. Biochem. Biophys. Res. Commun. 295, 796-799. doi:10.1016/S0006-291X(02)00762-3

Leitch, H. A., and Gattermann, N. (2019). Hematologic Improvement with Iron Chelation Therapy in Myelodysplastic Syndromes: Clinical Data, Potential Mechanisms, and Outstanding Questions. Crit. Rev. Oncol./Hematol. 141, 54-72. doi:10.1016/j.critrevonc.2019.06.002

Liu, H., Mu, L., Tang, J., Shen, C., Gao, C., Rong, M., et al. (2014). A Potential Wound Healing-Promoting Peptide from Frog Skin. Int. J. Biochem. Cel Biol. 49, 32-41. doi:10.1016/j.biocel.2014.01.010

Lv, Y., Liu, Q., Bao, X., Tang, W., Yang, B., and Guo, S. (2009). Identification and Characteristics of Iron-Chelating Peptides from Soybean Protein Hydrolysates Using IMAC-Fe ${ }^{3+}$. J. Agric. Food Chem. 57, 4593-4597. doi:10.1021/jf9000204

Machado, R. J. A., Estrela, A. B., Nascimento, A. K. L., Melo, M. M. A., Torres-Rêgo, M., Lima, E. O., et al. (2016). Characterization of TistH, a Multifunctional Peptide from the Scorpion Tityus Stigmurus: Structure, Cytotoxicity and Antimicrobial Activity. Toxicon 119, 362-370. doi:10.1016/j.toxicon.2016.06.002

Martin, R. L. (2003). Natural Transition Orbitals. J. Chem. Phys. 118, 4775-4777. doi:10.1063/1.1558471
Melo, M. M. A., Daniele-Silva, A., Teixeira, D. G., Estrela, A. B., Melo, K. R. T., Oliveira, V. S., et al. (2017). Structure and In Vitro Activities of a Copper IIChelating Anionic Peptide from the Venom of the Scorpion Tityus Stigmurus. Peptides 94, 91-98. doi:10.1016/j.peptides.2017.05.009

Melo-Silveira, R. F., Fidelis, G. P., Costa, M. S. S. P., Telles, C. B. S., Dantas-Santos, N., Elias, S. d. O., et al. (2012). In Vitro antioxidant, Anticoagulant and Antimicrobial Activity and in Inhibition of Cancer Cell Proliferation by Xylan Extracted from Corn Cobs. Int. J. Mol. Sci. 13, 409-426. doi:10.3390/ ijms13010409

Melo-Silveira, R., Fidelis, G., Viana, R., Soeiro, V., Silva, R., Machado, D., et al. (2014). Antioxidant and Antiproliferative Activities of Methanolic Extract from a Neglected Agricultural Product: Corn Cobs. Molecules 19, 5360-5378. doi:10.3390/molecules19045360

Mendes, L. F., Gaspar, V. M., Conde, T. A., Mano, J. F., and Duarte, I. F. (2019). Flavonoid-mediated Immunomodulation of Human Macrophages Involves Key Metabolites and Metabolic Pathways. Sci. Rep. 9, 1-10. doi:10.1038/ s41598-019-51113-z

Mosmann, T. (1983). Rapid Colorimetric Assay for Cellular Growth and Survival: Application to Proliferation and Cytotoxicity Assays. J. Immunol. Methods 65, 55-63. doi:10.1016/0022-1759(83)90303-4

Nascimento, A. K. L., Melo-Silveira, R. F., Dantas-Santos, N., Fernandes, J. M., Zucolotto, S. M., Rocha, H. A. O., et al. (2013). Antioxidant and Antiproliferative Activities of Leaf Extracts from Plukenetia volubilis Linneo (Euphorbiaceae). Evid.-Based Complement. Altern. Med. 2013, 950272. doi:10.1155/2013/950272

Nie, Y., Zeng, X.-C., Yang, Y., Luo, F., Luo, X., Wu, S., et al. (2012). A Novel Class of Antimicrobial Peptides from the Scorpion Heterometrus Spinifer. Peptides 38, 389-394. doi:10.1016/j.peptides.2012.09.012

Ojeda, P. G., Wang, C. K., and Craik, D. J. (2016). Chlorotoxin: Structure, Activity, and Potential Uses in Cancer Therapy. Biopolymers 106, 25-36. doi:10.1002/ bip. 22748

Ortiz, E., Gurrola, G. B., Schwartz, E. F., and Possani, L. D. (2015). Scorpion Venom Components as Potential Candidates for Drug Development. Toxicon 93, 125-135. doi:10.1016/j.toxicon.2014.11.233

Perdew, J. P. (1986). Density-functional Approximation for the Correlation Energy of the Inhomogeneous Electron Gas. Phys. Rev. B 33, 8822-8824. doi:10.1103/ PhysRevB.33.8822

Petricevich, V. L., and Lebrun, I. (2005). Immunomodulatory Effects of the Tityus Serrulatus Venom on Murine Macrophage Functions In Vitro. Mediators Inflamm. 2005, 39-49. doi:10.1155/MI.2005.39

Petricevich, V. L. (2002). Effect ofTityus Serrulatusvenom on Cytokine Production and the Activity of Murine Macrophages. Mediators Inflamm. 11, 23-31. doi:10.1080/09629350210308

Petricevich, V. L. (2010). Scorpion Venom and the Inflammatory Response. Mediators Inflamm. 2010, 1-16. doi:10.1155/2010/903295

Pivec, T., Kargl, R., Maver, U., Bračič, M., Elschner, T., Žagar, E., et al. (2019). Chemical Structure-Antioxidant Activity Relationship of Water-Based Enzymatic Polymerized Rutin and its Wound Healing Potential. Polymers (Basel) 11, 1-21. doi:10.3390/polym11101566

Poulos, T. L. (2014). Heme Enzyme Structure and Function. Chem. Rev. 114, 3919-3962. doi:10.1021/cr400415k

Pracht, P., Bohle, F., and Grimme, S. (2020). Automated Exploration of the LowEnergy Chemical Space with Fast Quantum Chemical Methods. Phys. Chem. Chem. Phys. 22, 7169-7192. doi:10.1039/C9CP06869D

Presa, F., Marques, M., Viana, R., Nobre, L., Costa, L., and Rocha, H. (2018). The Protective Role of Sulfated Polysaccharides from green Seaweed Udotea Flabellum in Cells Exposed to Oxidative Damage. Mar. Drugs 16, 135. doi:10.3390/md16040135

Pretorius, E., Bester, J., Vermeulen, N., Lipinski, B., Gericke, G. S., and Kell, D. B. (2014). Profound Morphological Changes in the Erythrocytes and Fibrin Networks of Patients with Hemochromatosis or with Hyperferritinemia, and Their Normalization by Iron Chelators and Other Agents. PLoS One 9, e85271. doi:10.1371/journal.pone.0085271

Pucca, M. B., Cerni, F. A., Pinheiro-Junior, E. L., Zoccal, K. F., Bordon, K. D. C. F., Amorim, F. G., et al. (2016). Non-Disulfide-Bridged Peptides from Tityus Serrulatus Venom: Evidence for Proline-free ACE-Inhibitors. Peptides 82, 44-51. doi:10.1016/j.peptides.2016.05.008 
Reed, A. E., and Weinhold, F. (1983). Natural Bond Orbital Analysis of near-HartreeFock Water Dimer. J. Chem. Phys. 78, 4066-4073. doi:10.1063/1.445134

Ren, Y., Wu, H., Lai, F., Yang, M., Li, X., and Tang, Y. (2014). Isolation and Identification of a Novel Anticoagulant Peptide from Enzymatic Hydrolysates of Scorpion (Buthus Martensii Karsch) Protein. Food Res. Int. 64, 931-938. doi:10.1016/j.foodres.2014.08.031

Sales, T. A., Prandi, I. G., Castro, A. A., Leal, D. H. S., Cunha, E. F. F. D., Kuca, K., et al. (2019). Recent Developments in Metal-Based Drugs and Chelating Agents for Neurodegenerative Diseases Treatments. Int J. Mol. Sci. 20, 1829. doi:10.3390/ijms20081829

Scalmani, G., and Frisch, M. J. (2010). Continuous Surface Charge Polarizable Continuum Models of Solvation. I. General Formalism. J. Chem. Phys. 132, 114110. doi:10.1063/1.3359469

Segura-Ramírez, P., and Silva Júnior, P. (2018). Loxosceles Gaucho Spider Venom: an Untapped Source of Antimicrobial Agents. Toxins 10, 522. doi:10.3390/ toxins10120522

Shi, W., He, P., Zeng, X.-C., Wu, W., and Chen, X. (2018). Inhibitory Effect of an Acidic Peptide on the Activity of an Antimicrobial Peptide from the Scorpion Mesobuthus Martensii Karsch. Molecules 23, 3314. doi:10.3390/molecules23123314

Silva, F. D., Rezende, C. A., Rossi, D. C. P., Esteves, E., Dyszy, F. H., Schreier, S., et al. (2009). Structure and Mode of Action of Microplusin, a Copper II-Chelating Antimicrobial Peptide from the Cattle Tick Rhipicephalus (Boophilus) Microplus. J. Biol. Chem. 284, 34735-34746. doi:10.1074/jbc.M109.016410

Singh, S., and Singh, R. P. (2008). In Vitro Methods of Assay of Antioxidants: An Overview. Food Rev. Int. 24, 392-415. doi:10.1080/87559120802304269

Smith, S. W. (2013). The Role of Chelation in the Treatment of Other Metal Poisonings. J. Med. Toxicol. 9, 355-369. doi:10.1007/s13181-013-0343-6

Thien, T. V., Anh, H. N., Trang, N. T. T., Trung, P. V., Khoa, N. C., Osipov, A. V., et al. (2017). Low-molecular-weight Compounds with Anticoagulant Activity from the Scorpion Heterometrus Laoticus Venom. Dokl. Biochem. Biophys. 476, 316-319. doi:10.1134/S1607672917050052

Tonin, T. D., Thiesen, L. C., de Oliveira Nunes, M. L., Broering, M. F., Donato, M. P., Goss, M. J., et al. (2016). Rubus Imperialis (Rosaceae) Extract and Pure Compound Niga-Ichigoside F1: Wound Healing and Anti-Inflammatory Effects. Naunynschmiedeberg's Arch. Pharmacol. 389, 1235-1244. doi:10.1007/s00210-016-1285-8

Torres-Rêgo, M., Furtado, A. A., Bitencourt, M. A. O., Lima, M. C. J. d. S., Andrade, R. C. L. C. d., Azevedo, E. P. d., et al. (2016). Anti-Inflammatory Activity of Aqueous Extract and Bioactive Compounds Identified from the Fruits of Hancornia Speciosa Gomes (Apocynaceae). BMC Complement. Altern. Med. 16, 1-10. doi:10.1186/s12906-016-1259-x

Torres-Rêgo, M., Gláucia-Silva, F., Rocha Soares, K. S., de Souza, L. B. F. C., Damasceno, I. Z., Santos-Silva, E. d., et al. (2019). Biodegradable Cross-Linked Chitosan Nanoparticles Improve Anti-Candida and Anti-biofilm Activity of TistH, a Peptide Identified in the Venom Gland of the Tityus Stigmurus Scorpion. Mater. Sci. Eng. C 103, 109830. doi:10.1016/j.msec.2019.109830

Tran, T., Hoang, A., Nguyen, T., Phung, T., Nguyen, K., Osipov, A., et al. (2017). Anticoagulant Activity of Low-Molecular Weight Compounds from Heterometrus Laoticus Scorpion Venom. Toxins 9, 343. doi:10.3390/toxins9110343

Valdez-Velázquez, L. L., Quintero-Hernández, V., Romero-Gutiérrez, M. T., Coronas, F. I. V., and Possani, L. D. (2013). Mass Fingerprinting of the Venom and Transcriptome of Venom Gland of Scorpion Centruroides Tecomanus. PLoS One 8, e66486. doi:10.1371/journal.pone.0066486

Valdez-Velázquez, L. L., Cid-Uribe, J., Romero-Gutierrez, M. T., OlamendiPortugal, T., Jimenez-Vargas, J. M., and Possani, L. D. (2020). Transcriptomic and Proteomic Analyses of the Venom and Venom Glands of Centruroides Hirsutipalpus, a Dangerous Scorpion from Mexico. Toxicon 179, 21-32. doi:10.1016/j.toxicon.2020.02.021

Veloso Júnior, P. H. d. H., Simon, K. S., de Castro, R. J. A., Coelho, L. C., Erazo, F. A. H., de Souza, A. C. B., et al. (2019). Peptides ToAP3 and ToAP4 Decrease Release of Inflammatory Cytokines through TLR-4 Blocking. Biomed. Pharmacother. 118, 109152. doi:10.1016/j.biopha.2019.109152

Wali, A., Wubulikasimu, A., Yanhua, G., Omar, A., Arken, A., Yili, A., et al. (2020). Separation and Purification of Antioxidant Peptides from Enzymatically Prepared Scorpion (Buthus Martensii Karsch) Protein Hydrolysates. Int. J. Pept. Res. Ther. 26, 1803-1818. doi:10.1007/s10989-019-09976-3

Wang, Q., and Franz, K. J. (2016). Stimulus-responsive Prochelators for Manipulating Cellular Metals. Acc. Chem. Res. 49, 2468-2477. doi:10.1021/ acs.accounts.6b00380
Wang, J., Zhang, Q., Zhang, Z., and Li, Z. (2008). Antioxidant Activity of Sulfated Polysaccharide Fractions Extracted from Laminaria Japonica. Int. J. Biol. Macromol. 42, 127-132. doi:10.1016/j.ijbiomac.2007.10.003

Ward, R. J., Dexter, D. T., and Crichton, R. R. (2012). Chelating Agents for Neurodegenerative Diseases. Cmc 19, 2760-2772. doi:10.2174/ 092986712800609689

Weigend, F., and Ahlrichs, R. (2005). Balanced Basis Sets of Split Valence, Triple Zeta Valence and Quadruple Zeta Valence Quality for $\mathrm{H}$ to Rn: Design and Assessment of Accuracy. Phys. Chem. Chem. Phys. 7, 3297-3305. doi:10.1039/b508541a

Wright, J. A., Richards, T., and Srai, S. K. S. (2014). The Role of Iron in the Skin and Cutaneous Wound Healing. Front. Pharmacol. 5, 1-8. doi:10.3389/fphar.2014.00156

Wu, W., Li, B., Hou, H., Zhang, H., and Zhao, X. (2017). Identification of IronChelating Peptides from Pacific Cod Skin Gelatin and the Possible Binding Mode. J. Funct. Foods 35, 418-427. doi:10.1016/j.jff.2017.06.013

Yanai, T., Tew, D. P., and Handy, N. C. (2004). A New Hybrid ExchangeCorrelation Functional Using the Coulomb-Attenuating Method (CAMB3LYP). Chem. Phys. Lett. 393, 51-57. doi:10.1016/j.cplett.2004.06.011

Yang, F., Jin, S., and Tang, Y. (2019). Marine Collagen Peptides Promote Cell Proliferation of NIH-3T3 Fibroblasts via NF-kB Signaling Pathway. Molecules 24, 4201. doi:10.3390/molecules 24224201

Yu, Y., Gutierrez, E., Kovacevic, Z., Saletta, F., Obeidy, P., Suryo Rahmanto, Y., et al. (2012). Iron Chelators for the Treatment of Cancer. Cmc 19, 2689-2702. doi:10.2174/092986712800609706

Zamyatina, A., and Heine, H. (2020). Lipopolysaccharide Recognition in the Crossroads of TLR4 and Caspase-4/11 Mediated Inflammatory Pathways. Front. Immunol. 11, 1-22. doi:10.3389/fimmu.2020.585146

Zeng, X.-C., Corzo, G., and Hahin, R. (2005). Scorpion Venom Peptides without Disulfide Bridges. IUBMB Life 57, 13-21. doi:10.1080/ 15216540500058899

Zeng, X.-C., Wang, S., Nie, Y., Zhang, L., and Luo, X. (2012). Characterization of BmKbpp, a Multifunctional Peptide from the Chinese Scorpion Mesobuthus Martensii Karsch: Gaining Insight into a New Mechanism for the Functional Diversification of Scorpion Venom Peptides. Peptides 33, 44-51. doi:10.1016/ j.peptides.2011.11.012

Zeng, X., An, H., Yu, F., Wang, K., Zheng, L., Zhou, W., et al. (2021). Benefits of Iron Chelators in the Treatment of Parkinson's Disease. Neurochem. Res. 46, 1239-1251. doi:10.1007/s11064-021-03262-9

Zhang, X., Jia, Q., Li, M., Liu, H., Wang, Q., Wu, Y., et al. (2021). Isolation of a Novel Calcium-Binding Peptide from Phosvitin Hydrolysates and the Study of its Calcium Chelation Mechanism. Food Res. Int. 141, 110169. doi:10.1016/ j.foodres.2021.110169

Zhao, Y., Dai, C., Wang, Z., Chen, W., Liu, J., Zhuo, R., et al. (2019). A Novel Curcumin-Loaded Composite Dressing Facilitates Wound Healing Due to its Natural Antioxidant Effect. Drug Des. Devel Ther. 13, 3269-3280. doi:10.2147/ DDDT.S219224

Zhdanova, N. G., Shirshin, E. A., Maksimov, E. G., Panchishin, I. M., Saletsky, A. M., and Fadeev, V. V. (2015). Tyrosine Fluorescence Probing of the SurfactantInduced Conformational Changes of Albumin. Photochem. Photobiol. Sci. 14, 897-908. doi:10.1039/x0xx00000x10.1039/c4pp00432a

Conflict of Interest: The authors declare that the research was conducted in the absence of any commercial or financial relationships that could be construed as a potential conflict of interest.

Publisher's Note: All claims expressed in this article are solely those of the authors and do not necessarily represent those of their affiliated organizations, or those of the publisher, the editors, and the reviewers. Any product that may be evaluated in this article, or claim that may be made by its manufacturer, is not guaranteed or endorsed by the publisher.

Copyright $\odot 2022$ Melo, Oliveira, Queiroz Neto, Paiva, Torres-Rêgo, Silva, Pontes, Rocha, Souza, Silva-Júnior and Fernandes-Pedrosa. This is an open-access article distributed under the terms of the Creative Commons Attribution License (CC BY). The use, distribution or reproduction in other forums is permitted, provided the original author(s) and the copyright owner(s) are credited and that the original publication in this journal is cited, in accordance with accepted academic practice. No use, distribution or reproduction is permitted which does not comply with these terms. 